\title{
Bilirkişilik Müessesesinde Yaşanan Sorunlarla İlgili Muhasebe Meslek Mensupları Ve Hakimlerin Algısı Üzerine Bir Araştırma*
}

\author{
Arzu MERİÇ* \\ Hakan ERKUŞ ${ }^{* *}$ \\ Mehmet KAYGUSUZOĞLU***
}

\begin{abstract}
$\ddot{O Z Z T}$
Uzmanlık alanlarının geliştiği ve ayrıntılı bir hal aldığı günümüzde hakimin teknik ve özel konularda bilgi sahibi olma ihtimali azalmaktadır. Bu durumda hakimin özel ve teknik bilgi sahibi kişilerden yardım istemesi gerekmektedir. Türk Hukuk Sistemimiz; çözümü, uzmanlı̆̆l, özel ve teknik bilgiyi gerektiren hallerde, sürecin hılanması ve adaletin sağlanması için, mahkemelere bilirkişiden yararlanma imkanını vermiştir. 3568 sayıl meslek yasasında SMMM ve YMM'lerin mali davalarda bilirkişilik yapmaları çalı̧̧ma konuları arasında belirlenmiştir.

Uzmanlaşmanın artmasıla yargıda bilirkişilik müessesesinin önemi gittikçe artmaktadır. Ancak zaman zaman bu önemli müessese amacından uzaklaşarak kendisinden beklenen faydayı sağlayamamaktadır. Bu çalışmada, bilirkişilik müessesesi ile ilgili yaşanan sorunların, muhasebe uzmanlık alanıyla ilgili bilirkişilik bağlamında, SMMM ve hakimlerce, değerlendirilmesi yapılarak, tespit edilen sorunların çözümü için öneriler oluşturulmuştur.

Bu amaçla, hazırlanan anket dava yoğunluğu fazla olan iller sıralamasına göre ilk üç il olarak İstanbul, Ankara ve İmir'de toplam 190 hakim ve 204 SMMM'ye yüzyüze uygulanmıştır. Araştırma sonuçlarına göre, bilirkişilik müessesesi için ifade edilen sorunların SMMM bilirkişiler için büyük oranda geçerli olmadiğı belirlenmiştir. Ancak SMMM'ler tarafindan yapılan bilirkişilik müessesesinin daha etkin bir hale getirilmesi beklentisi olduğu tespit edilmiştir.
\end{abstract}

Anahtar Kelimeler: Muhasebecilik, Bilirkişilik Müessesesi, Uzman Tanıklık.

JEL Sınıflandırması: M40, M41.

\section{A Study on The Perception of Accounting Professionals and Judges About The} Problems Encountered in Expert Witnessing

\section{ABSTRACT}

In our day, as the fields of expertise improve and get more detailed, the possibility of a judge to be knowledgeable with technical and specific subjects decreases. In such cases, the judge needs to ask for information to individuals having specific and technical knowledge. The Turkish Judicial System allows the courts to consult experts in order to accelerate the process and secure the justice, in cases the solution of which requires expertise and specific or technical knowledge. In the law act 3568, experts have been defined as duties in financial consultants and independent auditors' field.

The importance of the institution of expertise increases, as specialization rises. However, that important institution sometimes moves away from its aim and thus, is unable to provide the expected benefit. In this study, the problems of the institution of expertise were assessed in the context of expertise in specialized field of accounting, by the professionals of the field and judges, and suggestions were made as to the solution of identified problems.

To this end, the prepared survey was applied face-to-face on 190 judges and 204 independent accountants and financial advisors in İstanbul, Ankara and İmir which rank among the top three cities having the highest number of lawsuits. According to the results of the study, the problems expressed about the institution of expertise were found not to be substantially applicable for independent accountant and financial advisor experts. Nevertheless, it was confirmed that the expertise activities of independent accountants and financial advisors are expected to be more effective.

Keywords: Accountancy, Expert Witness Organization, Expert Witness.

Jel Classification: M40, M41.

\footnotetext{
* Bu çalışma “Türkiye'de Bilirkişilik Müessesesi Bağlamında Adli Muhasebe İle İlgili Bir Araştırma” doktora tezinden üretilmiştir.

* Öğr. Gör. Dr. Arzu Meriç, Adıyaman Üniversitesi, İktisadi ve İdari Bilimler Fakültesi, acengil@adiyaman.edu.tr

** Prof. Dr. Hakan Erkuş, İnönü Üniversitesi, İktisadi ve İdari Bilimler Fakültesi, hakan.erkus@inonu.edu.tr

*** Doç. Dr. Mehmet KAYGUSUZOĞLU,Adıyaman Üniversitesi, İktisadi ve İdari Bilimler

Fakültesi, mkaygusuzuglu@ adiyaman.edu.tr
} 


\section{GíRiş}

Son yüzyıl içinde insanoğlunun edindiği bilgi miktarının, insanlığın başlangıcından beri edindiği miktara yakın olduğu iddia edilmektedir. Bu iddiayı doğrularcasına, bilim ve teknoloji geçtiğimiz yüzyıl içinde baş döndürücü bir hızla gelişmiştir ve gelişmeye devam etmektedir. Bu sayede insanların bilgi düzeyi artmış, icra edilen meslekler çok daha karmaşık bir hal almış ve bu nedenle kişiler mesleklerinde uzmanlaşma yoluna gitmişlerdir. Bilgi düzeyinin yükselmesine paralel olarak, uyuşmazlıkları çözmekle görevli olan hakimlerin işi de bir hayli zorlaşmışır (Bulut, 2001: 1).

Bilirkişilik, yargılamada hakimin hukuk bilgisi dışında uzmanlığı gerektiren bilgiye ihtiyaç duyması durumunda, yargılamada hakimin işini kolaylaştıran yollardan birisidir. Özellikle son yıllarda daha ayrıntılı uzmanlık alanlarının oluşmaya başlaması ile birlikte alanlarında uzman bilirkişilerin davalardaki işlevleri artmaya başlamıştır.

Yarg1 kararları çoğu zaman bilirkişi raporuna dayanmakta ve bilirkişi adalet dağıtımında çok önemli ve etkin bir rol oynamaktadır. Bilirkişinin yasal ve vicdani çok önemli sorumlulukları bulunmaktadır. Bu nedenle görevin sağlıklı biçimde tanımlanması ve büyük bir titizlikle uygulanması gerekmektedir. Bu günkü uygulamada bilirkişilik anlamını, önemini ve saygınlığını önemli ölçüde yitirmiş görünmektedir (Tankut ve Ersoy, 2014: 877).

\section{BİLİRKIŞSiLIKK MÜESSESESİ İLE İLGILII KAVRAMLAR}

Yarg1 görevinin yerine getirilmesi önceden belirlenen birtakım usullere bağlanmıştır. "Muhakeme hukuku" adı altında toplayabileceğimiz bu usuller, medeni muhakeme, ceza muhakemesi ve idari muhakeme gibi bölümlere ayrılmaktadır. Muhakeme hukuku, devletin yargı gücünü temsil eden organlarının, uyuşmazlıkları çözerken izleyecekleri yöntemleri düzenleyen hukuk dalıdır (Centel ve Zafer, 2008: 3). Bilirkişilik kurumu, yargılama usulüne ilişkin kanunlarımızda düzenlenmiş bir konudur. Yargılama usulüne ilişkin kanunlarımız, mahkemeye gelen bir dava veya talebin hukuka uygun ve akılcı bir yöntemle karara bağlanması amacıyla izlenecek usul ve esasları gösteren kurallar bütünüdür ve bilirkişilik kurumu ile ilgili hükümler de yer almaktadır.

İlk zamanlarda bilirkişilik kurumunun olmaması nedeniyle bu boşluk benzer kavramlardan yararlanılarak ifade edilmiş, örneğin bilirkişi "tanık", "seçkin tanık", "hukuk danışmanı", "arbiter", "keşfin bir vasıtası", gibi kavramlar içerisinde değerlendirilir olmuştur. Yürürlükten kalkan usul kanunlarımızda "ehlihibre" ve "ehli vukuf", doktrinde "ekspertiz", "resmi muhammim" gibi tanımlar kullanılsa da günümüzde artık "bilirkişi kavramı" bir bütün olarak belirtilen kavramların yerine kullanılmakta ve yenilenen usul kanunlarımızda söz konusu kavram geçmektedir (Çınar, 2009: 7-8).

Usul kanunlarımızda bilirkişilik kurumu ayrıntılı olarak düzenlenmiştir ancak bilirkişinin tanımı yapılmamıştır. Bilirkişi kavramının tanımı için kanun hükmünde gerekli bazı unsurlara yer verilmiştir. Örneğin, "Mahkeme, çözümü hukuk dışında, özel ve teknik bir 
bilgiyi gerektiren hallerde bilirkişinin oy ve görüşünün alınmasına karar verir.” (HMK m. 266) hükmünde1; bilirkişinin tanımı, yargılama sürecinde özel ve teknik bir bilgiyi gerektiren konularda hakim tarafindan bilgi ve görüşüne başvurulan uzman kişiler şeklinde bir çıkarımla yapılabilir.

Sözlüklerde bilirkişi; belli bir konuda iyi anlayan ve bir anlaşmazlığı çözümlemek için kendisine başvurulan kimse; çözümü özel veya teknik bir bilgiyi gerektiren hallerde oy ve görüşüne başvurulan kişi; ehli vukuf, "iyi bilgisi olan", ehli hibre ise "bir şeyi çok iyi bilen" şeklinde tanımlanmıştır (Mecek, 2011: 4). Literatürde farklı bilirkişi tanımları bulunmaktadır:

Bilirkişi özel ve teknik konuda hazırladığı raporla mahkemenin karar vermesini kolaylaştıran ve yardım eden kişidir. Bilirkişi, hakim tarafından özel ve teknik bilgisi ve yetenekleri göz önünde bulundurularak seçilen bir veya daha fazla kişidir (Yıldırım vd., 2011: $14)$.

Bir davanın çözüme kavuşturulması bakımından önem taşıyan, açıklığa kavuşturulması ya da tespiti özel veya teknik bilgiyi gerektiren hususlarda, mahkemece oy ve görüşüne başvurulan üçüncü kişi ya da kişilere bilirkişi denir (Tanrıver, 2009: 575).

Bilirkişinin, özellikle maddi vakanın, maddi gerçekliğin tespitinde, ortaya konmasında tanık gibi hakim yardımcısı, dolayısıyla bir ispat aracı olarak düşünülmesi mümkündür. Bilirkişinin yaptığı iş bir anlamda danışmanlık hizmetidir. Bilirkişilik müessesesi yarg1 sisteminin işleyişi ve adil yargılamanın sağlanması açısından büyük bir öneme sahiptir.

\section{BİLİRKISSILIIK KURUMU İLE İLGILİ KARȘILAȘILAN SORUNLAR}

Hukuki uyuşmazlıkların çözümünde özel veya teknik bilgisi ile hakime yardımcı olan bilirkişi, yarg1 sistemi içerisinde büyük bir öneme sahiptir. Ancak, bilirkişilik kurumunun yaşanan bir takım sıkıntılar nedeniyle yargının en önemli sorunlarından biri olduğu iddia edilmektedir.

Dünya Bankasının desteğiyle bilirkişilik müessesesi, konunun uzmanı yabancı akademisyenlerin de katılımı ile 1 Kasım 2010 tarihinde düzenlenen bir çalıştay ile ele alınmıştır. Bu amaçla Dünya Bankası tarafindan Fransa, Almanya, İtalya ve ABD'deki bilirkişilik uygulamalarını inceleyen ve ülkemiz uygulamasını göz önünde bulundurarak çeşitli çıkarımlarda bulunan bir rapor hazırlanmıştır. Ayrıca yine konuyla ilgili Adalet Bakanlığı'nın İç Denetim Birimi Başkanlığı'nca 2010 yılı iç denetim programına istinaden araştırma- inceleme gerçekleştirilmiş buna ilişkin bilirkişilik müessesesiyle ilgili sorunların yer aldığı bir rapor daha hazırlanmıştır (ABGM, 2010). Konuyla ilgili olarak yapılan akademik araştırmalar da incelendiğinde (Akyol, 1991, Arslan, 2000, Așçığlu, 2000, Salkaya, 2000, Törüner, 2000, Bulut, 2001, Deryal, 2004, İnan, 2005, Soydan, 2008, Çınar, 2009, Tanrıver, 2009, Yücel, 2011) bilirkişilik müessesesinde yaşanan sorunlar aşağıdaki gibi siralanabilir:

\footnotetext{
${ }^{1}$ Benzer hüküm CMK m.63 ile ifade edilmiştir.
} 


\section{Bilirkişiden Kaynaklanan Sorunlar:}

$>$ Alanında yetkin (ehliyetli, uzman) olmayan kişilerin bilirkişi olarak görevlendirilmesi.

Bilirkişilerin toplum içerisinde çeşitli meslek gruplarıla iç içe olmaları sebebiyle ya da sürekli aynı kişilerin bilirkişi olarak atanması sebebiyle tarafsız davranamamasi.

Tarafsızlı̆̆ı sağlamaya yönelik vicdani baskı yaratan yemin kurumunun ciddiyete alınmaması ve bilirkişilere usulüne uygun yemin verdirilmemesi.

$>\quad$ Bilirkişilerin, gerçeği saklayan veya çarpıtan raporlar düzenleyerek adaleti yanıltmaları.

Dava konusunun kendi uzmanlık alanı dışında olduğunu bilmelerine rağmen, bilirkişilerin durumu yetkili makama bildirmemeleri.

Bilirkişilerin rapor hazırlamakta zorlandıkları konularda raporu kısmen ya da tamamen alt bilirkişilere tanzim ettirmeleri.

$>$ Hakim tarafından bilirkişiye gönderilen dosyaların etraflica incelenmemesinden, sorunlar ve yardım istenen konular açık ve net bir şekilde ortaya konulmamasından veyahut uyuşmazlıkla ilgili bilgi ve belgelerin gönderilmemesinden veya eksik gönderilmesinden dolayı kendilerine gelen uyuşmazlığı tam olarak anlayamaması durumunda bilirkişilerin görev alanını ve sınırlarını tam olarak kavrayamaması.

Bilirkişilerin davanın tarafları ile, dosyada eksik bilgi ve belgelerin tamamlanması veya bazı hususların açıklığa kavuşturulması gibi nedenlerle yasal olmazsa da ilişki içerisine girmeleri. Mahkeme tarafindan belirlenen ücretten ayrı ve farklı ücretlerin taraflar tarafından bilirkişiye önerilmesi.

$>\quad$ Raporların yeterli araştırma ve inceleme yapılmadan hazırlanması.

$>\quad$ Bilirkişiler tarafindan gerekçesiz rapor hazırlanması, olay hakkında sadece soyut görüş bildirilmesi.

Bilirkişilerin kurul teşkil edecek bir şekilde görevlendirildiğinde, gerekli hassasiyeti gösterip, koordineli bir biçimde ortaklaşa bir çalışma yapmamaları. Raporun kurulda yer alan bir bilirkişi tarafından hazırlanması, diğerlerinin ise sadece imza ile çalışmaya katılmaları.

\section{Hakimden Kaynaklanan Sorunlar:}

$>\quad$ Bilirkişi listelerinin meslek örgütleri ile yeterince işbirliği yapılmadan ve kişilerin yetkinlikleri objektif kıstaslarla değerlendirilmeden sağlıksız bir şekilde oluşturulması. Hakimin bilirkişi görevlendirmelerinde kullandığı il adli yargı komisyonlarınca düzenlenen listelerin sadece ceza davalarında kullanılması, hukuk ve idari yargıda görülmekte olan davalarda böyle bir listenin oluşturulmaması.

Bilirkişi seçiminde ve görevlendirilmesi hususunda hakimin yeterli ve gerekli dikkat ve özeni göstermemesi. Hakimlerin iş yoğunluğu sebebiyle yersiz bilirkişi incelemeleri 
yaptırmaları ve uyuşmazlık ile ilgili etraflıca inceleme yapmadığından bilirkişiden talep edilen hususun tam olarak açık ve net bir şekilde belirtmemeleri.

Bilirkişi raporları ile ilgili olarak gerekli görülürse duruşmada bilirkişiden açıklamalar yapması istenmesi husussunda yasa hükmü olmasına rağmen, genellikle bilirkişilerin duruşmalarda dinlenmemesi.

$>\quad$ Bilirkişilerin hukuki statüsü, yetkileri, yükümlülükleri ve sorumlulukları hususunda yeterli yasal düzenlemenin bulunmaması ve bilirkişiler için disiplin mekanizmasının bulunmamasi.

\section{Bilirkişi Raporları İle İlgili Sorunlar:}

$>\quad$ Raporun süresi ${ }^{2}$ içinde mahkemeye sunulması hususunda hem yarg1 mercileri hem de bilirkişiler tarafindan gerekli hassasiyetin gösterilmemesi. Ayrıca uygulamada rapor ve eklerini süresinde vermeyen bilirkişilere disipliner ve cezai yaptırımların uygulanmasında gerekli duyarlılık ve özenin gösterilmemesi.

$>\quad$ Uygulamada "dosyanın bilirkişiye tevdiine", "dosya ve eklerinin bilirkişiye havalesine", "tarafların iddia ve savunmaları karşısında bilirkişinin görüşünün alınmasına" gibi genel ibarelerin kullanılarak bilirkişilerden yardım istenmesi. Görev alanı ve sınırın açık ve net bir şekilde tam olarak belirtilmemesi. Tarafların görüşü alınmadan özellikle hangi sorulara cevap istendiği hususu açık ve kesin bir dille belirtilmeden bilirkişilerden rapor istenmesi ve içerik yönünden yetersiz raporların alınması.

\section{Bilirkişi İncelemesinin Kapsamı İle İlgili Sorunlar:}

$>\quad$ Mahkemeler her konuda ve en küçük tereddütte yeterince araştırma ve inceleme yapmadan, kanunda aksi hüküm olmasına rağmen genel ve hukuki konularda bile bilirkişiye başvurulması.

\section{Bilirkişi Ücreti İle İlgili Sorunlar:}

$>\quad$ Bilirkişi ücretlerinin dava miktarı ile orantılı olmaması ve çok düşük kalması. Böyle bir durumun görevin ehil ve uzman kişilerce tercih edilmemesi, bilirkişilik görevinden kaçınamayanların ise isteksiz ve ciddiyetsiz bir şekilde çalışmaları ya da mahkeme dişında taraflardan ücretten ayrı menfaatler beklenmesi gibi sorunlara yol açması.

\section{ARASTTIRMA}

\subsection{Araştırmanın Amacı ve Yöntemi}

Bilirkişilik müessesesi hakkında, müessesesinin problemlerini dile getiren pek çok yazınla karşılaşılmıştır. Söz konusu problemlerin, muhasebe uzmanlık alanıyla ilgili bilirkişilik kurumunu kapsayıp kapsamadığı araştırılmıştır, ayrıca belirtilen sorunların çözümü için öneriler oluşturulmuştur.

\footnotetext{
${ }^{2}$ Rapor verme süresi; işin niteliğine göre belirlenmekte olup, kanunda üst sınır üç ay olarak belirlenmiştir.
} 
Araştırma anket yöntemi ile gerçekleştirilerek, hazırlanan anket formu3 hakimler ve SMMM'lere yüz yüze uygulanmıştır. Anket formu ulaşılmak istenen amaca yönelik olarak 5 bölümden oluşmaktadır. Birinci bölüm, katılımcıların demografik özelliklerini belirlemeye yönelik 7 soru, ikinci, üçüncü, dördüncü bölümler bilirkişilik müessesesinde yaşanan sorunlarla ilgili olarak katılımcıların algıları beşli Likert ölçeği ile ölçülmesine yönelik 37 sorudan oluşmaktadır.

Anket yöntemiyle toplanan veriler SPSS 20.0 paket programına aktarılmış ve frekans dağılımı, ortalamalar, güvenilirlik, faktör analizi, T Testi, Korelasyon Testi gibi istatistiki yöntemler kullanılarak analiz edilmiştir.

\subsection{Araştırmanın Evreni ve Örneği}

Çalışmanın hedef kitlesini Türkiye'deki hakimler ve Serbest Muhasebeci Mali Müşavirler oluşturmaktadır. Türkiye Cumhuriyeti'nde mevcut olan yargı teşkilatı; adli yarg1 mahkemeleri ve idari yargı mahkemeleri olmak üzere ikiye ayrılmaktadır. Çalışmamızda adli yarg1 mahkemelerinde görev yapan, muhasebeci bilirkişisinden destek alan hakimlerle ve bilirkişi listelerinde yer alan SMMM'lerle anketler yapılmıştır.

Anketin yapılacağı yerler İstanbul, Ankara ve İzmir olarak belirlenmiştir. Söz konusu yerler, Adalet Bakanlığı, Adli Sicil ve İstatistik Genel Müdürlüğü’nün yayımladığı “Adli İstatistikler 2012" başlıklı raporuna göre hukuk mahkemelerinde açılan davalarda yoğunluk gösteren illerdir. Bu iller dava sayısı sıralamasında ilk üç şehirdir.

Hakimler ve Savcılar Yüksek Kurulu'nun 2012-2016 Stratejik Planında; Adli Yargı'da 2011 yılı itibariyle toplam 5.343 kişi hakimin görev yaptı̆̆ 1 tespit edilmiştir. Anketin yapılacağı iller olarak belirlenen illerde hakim sayısı 3414 kişidir ve $\% 95$ güven düzeyinde örneklem hacmi 1815 hakim olarak hesaplanmıştır. Hata payı \%4,746 şeklinde düşürülerek 190 hakim ile anket yapılmıştır.

Çalışmada, değerlendireceğimiz mahkemelerde, muhasebe desteği verebilecek SMMM toplam sayısı 76.832 kişidir.7 Araştırma için seçilen illerdeki adalet komisyonlarınca belirtilen bilirkişi listelerinde yer alan SMMM sayısı 1.782 kişidir8 ve \%95 güven düzeyinde örneklem hacmi 3179 SMMM olarak hesaplanmıştır. \%6,4610 hata payı ile evreni temsil eden 204 SMMM ile anketler yapılmıştır.

\footnotetext{
${ }^{3}$ Anket soruları gerekli literatür taraması yapıldıktan sonra, hedef kitle ile sözlü mülakatlar neticesinde oluşturulmuş olup, taslak olarak Adıyaman'da SMMM ve hakimlere pilot olarak uygulanmıştır. Güvenilirlik analizi yapılmış ve sonuç 0,883 çıkmıştır. Taslak revize edilerek anket esas çalışmaya hazır hale getirilmiştir.

${ }^{4}$ Nisan 2014 her bir şehirdeki adliye sitelerinden alınan verilerdir.

${ }^{5}$ www.raosoft.com sitesinden yararlanılmıştır.

${ }_{7}^{6}$ www.surveysystem.com sitesinden yararlanılmıştır.

7 TÜRMOB'un üye istatistikleri ile ilgili 2014'te hazırladığı rapordan derlenmiştir.

${ }^{8}$ Adliye Komisyonlarınca çıkarılan bilirkişi listelerinden derlenmiştir.

${ }^{9}$ www.raosoft.com sitesinden yararlanılmıştır.

${ }^{10}$ www.surveysystem.com sitesinden yararlanışmıştır.
} 
Basit tesadüfi örnekleme yöntemi ile belirlenen örneklemin illere dağglımı; İstanbul'da 100 hakim, 100 SMMM, Ankara'da 50 hakim, 50 SMMM ve İzmir'de 50 hakim, 50 SMMM şeklinde tespit edilmiştir. Yöntem olarak, yüz yüze anket yöntemi uygulanmıştır.

\subsection{Araştırmanın Sonuçları ve Sonuçların Değerlendirilmesi}

Çalışmada katılımcı olarak hakimlerin ve SMMM'lerin genel özelliklerini belirlemek amacıyla hazırlanan sorulara ilişkin elde edilen bulgular ve frekans dağılımları aşağıdaki tabloda verilmiştir.

Tablo 1: Katılımc1ların Genel Özellikleri

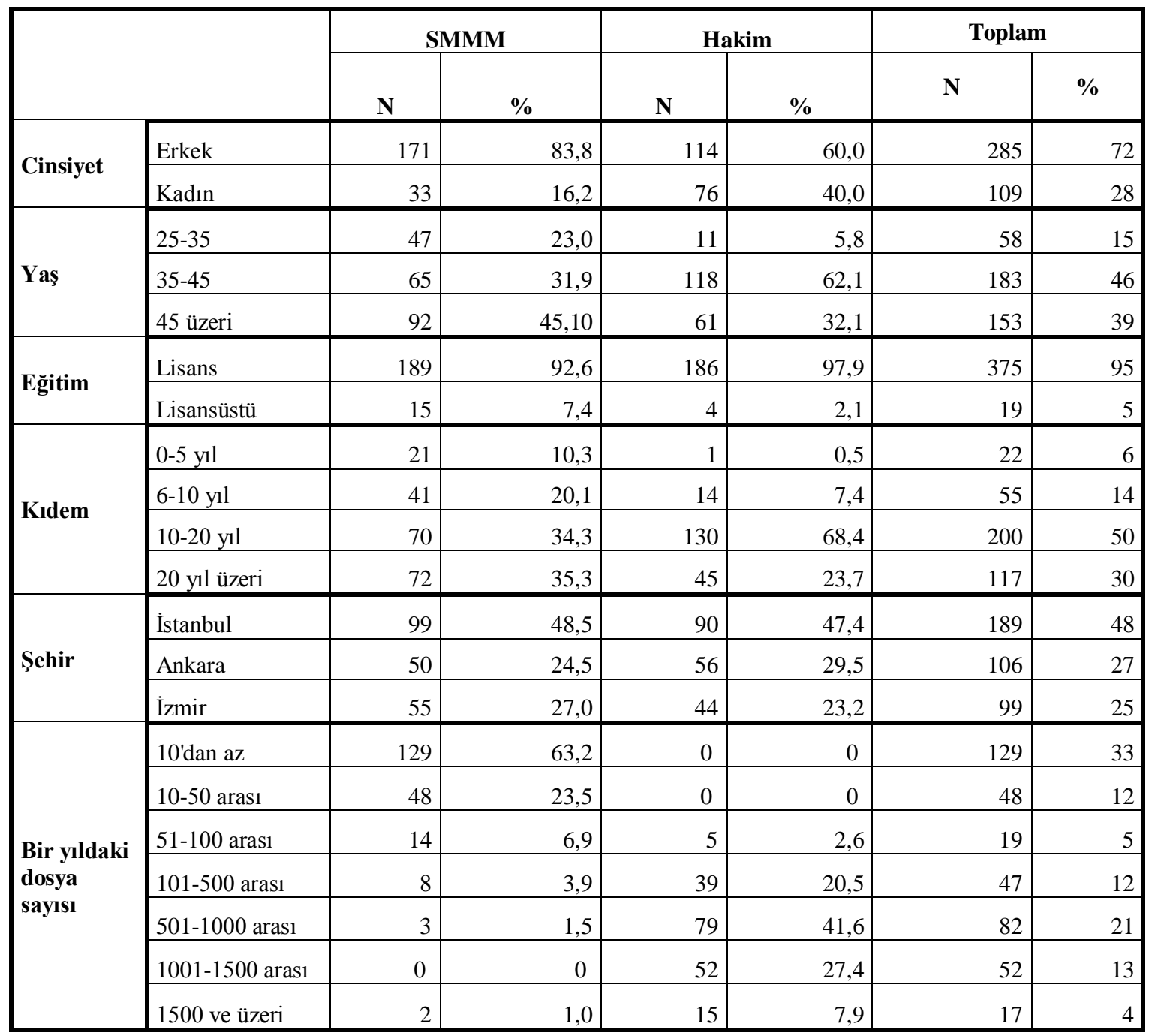

Tablo 1'de görüleceği üzere ankete katılanların \%72'si erkektir. Kat1lımcıların büyük çoğunluğu (\%85) 35 yaş üzeri olup, iş tecrübesi 10 yılın üzerindedir. Hakimlerin \%68'i 10-20 y1l arası deneyimli, \%24'ü 20 yıl üzeri deneyimli ve SMMM'lerin \%34'ü 10-20 yıl aras1 deneyimli, \%35'i 20 yıl üzeri deneyimlidir. Araştırmanın deneyimli, mesleğinde ehil kişiler üzerinde uygulanması avantajı edinilmiştir. Ankete katılanların \%95'i lisans mezunudur, \%48 
Hakim, \%52'si SMMM'lerden oluşmaktadır. Kat1lımcıların \%55'i 100'ün üzerinde dosya ile bilirkişilik müessesesinin içindedir.

\subsection{Faktör, Güvenilirlik ve Korelasyon Analizi Sonuçları}

Faktör analizi, birbirleriyle ilişkili çok sayıda değişkenden oluşan veri setini birbirinden bağımsız ve daha az sayıda yeni değişkenler içeren veri setlerine dönüştürmek kısacası veri indirgemek için başvurulan bir yöntemdir (Özdamar, 2013:209). Veri setinin faktör analizine uygunluğunun değerlendirmesinde; korelasyon matrisinin oluşturulması, Barlett testi ve Kaiser-Meyer-Olkin (KMO) testleri olarak isimlendirilen üç yöntem kullanılmaktadır (Kalayc1, 2010:321).

Tablo 2: KMO Analizi Tablosu

\begin{tabular}{|l|c|c|}
\hline \multicolumn{3}{|c|}{ KMO and Bartlett's Test } \\
\hline \multicolumn{2}{|c|}{ Kaiser-Meyer-Olkin Measure of Sampling Adequacy. } &, 947 \\
\hline Bartlett's Test of Sphericity & Approx. Chi-Square & 8368,484 \\
\cline { 2 - 3 } & Df & 12751 \\
\cline { 2 - 3 } & Sig. & 0,000 \\
\hline \multicolumn{2}{|c|}{ Eigen Value (Topl. Özdeğer) } & 0,43 \\
\hline
\end{tabular}

Tablo 2'ye göre; bilirkişilik müessesesinin muhasebeciler kapsamında değerlendirilmeye çalışıldığ 44 sorudan oluşan faktör değişkenlerinin genel olarak KMO değerinin 0,50'den büyük olması $(0,947)$ ve Barlett değerinin 0,000 olması nedeniyle değişkenlerin faktör analizine uygun oldukları sonucu elde edilmiştir. Faktörlerin toplam varyansı açıklama oranları ise $0,43^{\prime}$ tür.

Ankette bilirkişilik müessesesi ile ilgili yaşanan sorunlar dört boyutta değerlendirilmiş olup;

1. Boyut: Bilirkişilerin nitelikleri ile ilgili karşılaşılan sorunları içerdiğinden "Bilirkişi Nitelikleri”" şeklinde isimlendirilmiş ve "BN" şeklinde kodlanmıştır.

2. Boyut: Bilirkişilerin görevlendirilmeleri ile ilgili karşılaşılan sorunları içerdiğinden "Bilirkişi Görevlendirilmeleri" şeklinde isimlendirilmiş ve "GR" şeklinde kodlanmıştır.

3. Boyut: Bilirkişilerin görevlerini ifa ederken karşılaşılan sorunları içerdiğinden "Bilirkişi Görevleri” şeklinde isimlendirilmiş ve "BG" şeklinde kodlanmıştır.

4. Boyut: Bilirkişilerin hazırladığı raporlar ile ilgili karşılaşılan sorunları içerdiğinden "Bilirkişi Raporları" şeklinde isimlendirilmiş ve "BR" şeklinde kodlanmıştır.

Aşağıdaki tabloda yapılan faktör analizine ilişkin bulgular yer almaktadır. 
Tablo 3: Faktör Analizi Tablosu (Döndürülmüş Faktör Yükleri)

\begin{tabular}{|c|c|c|c|}
\hline Faktörler & Faktör Yükleri & Cronbach's Alpha & Faktörlerdeki Değişken Sayısı \\
\hline$\overline{\text { BN } 1}$ & 805 & \multirow{4}{*}{0,69} & \multirow{4}{*}{ 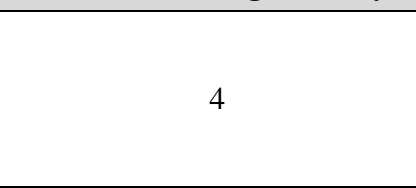 } \\
\hline BN 2 & 459, & & \\
\hline BN 3 & 830 & & \\
\hline BN 4 &, 780 & & \\
\hline GR 1 & ,706 & \multirow{12}{*}{0,812} & \multirow{12}{*}{12} \\
\hline GR 2 & ,627 & & \\
\hline GR 3 & 484, & & \\
\hline GR 4 & ",397 & & \\
\hline GR 5 & ,445 & & \\
\hline GR 6 &, 710 & & \\
\hline GR 7 & ,728 & & \\
\hline GR 8 & ,652 & & \\
\hline GR 9 &, 536 & & \\
\hline GR 10 & ,697 & & \\
\hline GR 11 & ",165 & & \\
\hline GR 12 & ,673 & & \\
\hline BG 1 & ,265 & \multirow{4}{*}{0,656} & \multirow{4}{*}{4} \\
\hline BG 2 & ,820 & & \\
\hline BG 3 & 800 & & \\
\hline BG 4 & ,657 & & \\
\hline BR 1 &, 622 & \multirow{16}{*}{0,857} & \multirow{16}{*}{17} \\
\hline BR 2 & 617 & & \\
\hline BR 3 &, 730 & & \\
\hline BR 4 &, 504 & & \\
\hline BR 5 &, 523 & & \\
\hline BR 6 & ,694 & & \\
\hline BR 7 & ,644 & & \\
\hline BR 8 &, 548 & & \\
\hline BR 9 &, 595 & & \\
\hline BR 10 &, 708 & & \\
\hline BR 11 &, 570 & & \\
\hline BR 12 &, 722 & & \\
\hline BR 13 &, 819 & & \\
\hline BR 14 &, 760 & & \\
\hline BR 16 &, 528 & & \\
\hline BR 17 & ,656 & & \\
\hline
\end{tabular}

*Faktör yükleri 0,40’ın altında olduğu için analizlerden çıkarılmıştır.

Faktör analizinde veri sayısı 350 ve üzerinde ise maddelerin faktör yüklerinin 0,40 ve üzerinde olması kabul görmektedir (Kalayc1, 2010:330). Buna göre; GR 4, GR11, BG 1 ve BR 15 faktör maddeleri analizler dişında tutulmuştur.

Güvenirlik katsayısı 0 ile 1 arasında değerler ile ölçülür. Değer 1'e yaklaştıkça güvenirlik düzeyi artış gösterir. Cronbach's Alpha değerlerinin yorumlanması aşağıda belirtilmiştir. Ölçek $(\alpha)$; 


$$
\begin{array}{ll}
> & 0,00 \leq \alpha<0,40 \text { ise güvenilir değil,. } \\
> & 0,40 \leq \alpha<0,60 \text { ise güvenirliği düşük, } \\
> & 0,60 \leq \alpha<0,80 \text { ise oldukça güvenilir, } \\
> & 0,80 \leq \alpha<1,00 \text { ise yüksek derecede güvenilir, }
\end{array}
$$

olarak kabul edilir (Kayış, 2010:403).

Toplamda 394 kişiye uygulanan anketimize güvenilirlik analizi yapılmış ve Cronbach's Alpha değeri 0,938 çıkmıştır. Elde edilen sonuca göre anketimize verilen cevaplar yüksek derecede güvenilir kabul edilebilir.

Her bir faktör için güvenilirlik katsayıları da faktör analizi sonuçlarıyla beraber değerlendirilmiştir. Yapılan faktör analizi sonucunda 4 faktörden birincisi "Bilirkişi Nitelikleri” (BN) olarak adlandırılan faktörün hesaplanan güvenirlik değeri 0,690 olmuştur. Ayrıca maddelerin faktör yükleri incelendiğinde en düşük yük BN $2(0,459)$ faktör maddesinde ve en yüksek yük ise BN $3(0,830)$ faktör maddesinde olmuştur. Elde edilen sonuçlara göre bu faktör grubunda yer alan sorulara verilen cevaplar oldukça güvenilir kabul edilebilir. Faktör yükleri değerlendirildiğinde, 0,40 ve üzeri değerler kabul edilebilir. En düşük yük olarak 0,459 kabul edilebilir bir değer olup, söz konusu anket sorusunun oluşturulan grupla ilgisinin olduğunu ifade etmektedir. Elde edilen sonuçlara göre bu faktör grubunda ilgisiz soru bulunmamaktadır.

Tablo incelendiğinde Bilirkişilerin Görevlendirmeleri (GR) olarak adlandırılan ikinci faktörün hesaplanan güvenirlik değeri 0,812 olarak gerçekleşmiştir. Güvenirliği kabul edilebilecek bu değerler ile birlikte bu maddelerin faktör yükleri incelendiğinde en düşük yük GR $5(0,445)$ faktör maddesinde ve en yüksek yük ise GR $7(0,728)$ faktör maddesinde olmuştur. Elde edilen sonuçlara göre bu faktör grubunda yer alan sorulara verilen cevaplar yüksek derecede güvenilir kabul edilebilir. GR 4 ve GR 11 faktör maddeleri 0,40'ın altında olduğu için analizden çıkarılmıştır. Diğer değerler kabul edilebilir aralıktadır. GR4 ve GR 11 hariç bu grupta ilgisiz soru bulunmamaktadır.

Bilirkişilerin Görevleri (BG) olarak adlandırılan faktörde, faktör yükü en düşük olan değişkenin 0,657 ile BG 4, faktör yükü en yüksek olan değişkenin ise 0,820 ile BG 2 olduğu görülmektedir. Faktörün güvenirlik düzeyi 0,656 olarak hesaplanmıştır. Elde edilen sonuçlara göre bu grupta yer alan sorulara verilen cevaplar oldukça güvenilir kabul edilebilir. BG 1 faktör maddesi 0,40 ' in altında olduğu için çıkarılmıştır. Diğer değerler kabul edilebilir aralıkta olup BG1 hariç grupta ilgisiz soru bulunmamaktadır.

Bilirkişi Raporları (BR) olarak adlandırılan kısımda en düşük faktör yükü 0,504 olarak BR 4, en yüksek faktör yükü 0,819 ile BR 13'tür. Güvenilirlik 0,857 olarak hesaplanmıştır. Elde edilen sonuçlara göre BR olarak adlandırılan faktörde yer alan sorulara verilen cevaplar yüksek derecede güvenilir kabul edilebilir. Faktör grubu içerisinde yer alan BR 15 faktör 
maddesi analiz dışında tutulmuştur. Diğer değerler kabul edilebilir aralıkta ve gruplarda ilgisiz soru bulunmamaktadır.

Tablo 4: Korelasyon Tablosu

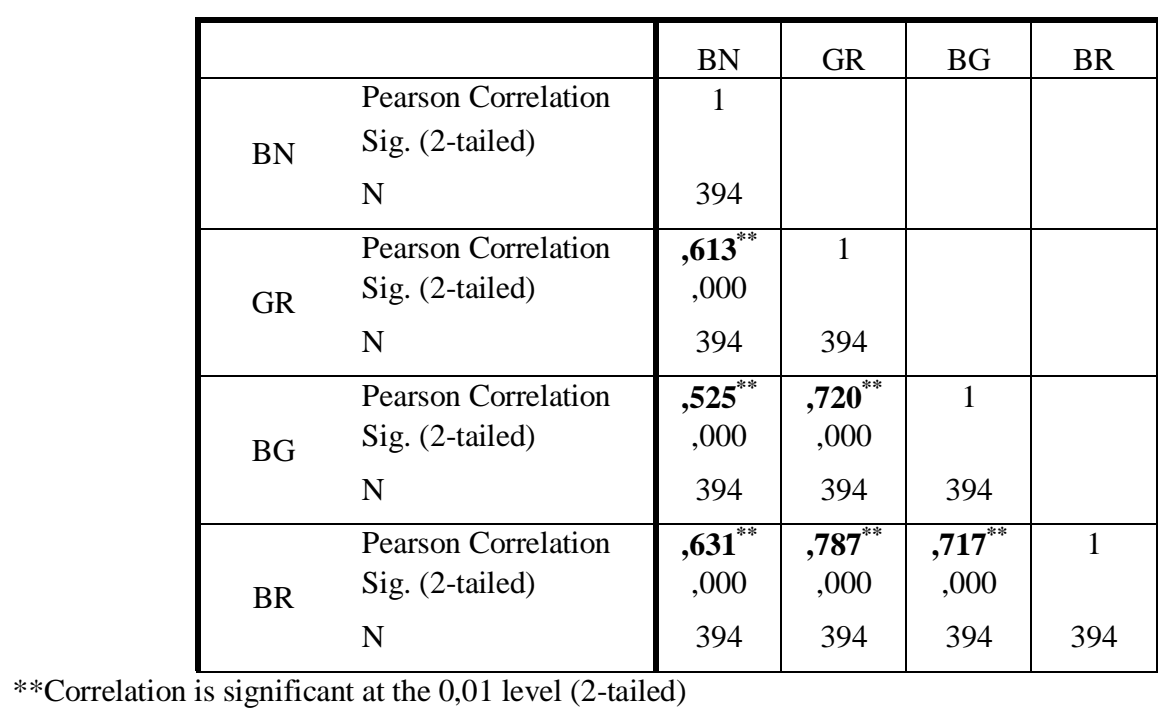

Korelasyon analizi ile, bilirkişilik müessesesinin muhasebeciler kapsamında değerlendirilmesine yönelik oluşturulan anketteki sorulara verilen cevapların yer aldıkları faktör grupları itibariyle birbirleri arasında ilişki düzeyi, derecesi, yönü ve anlamlılı̆̆ ölçülmüştür. Pearson korelasyon analizi sonuçları aşağıdaki kriterlere göre yorumlanır (Sungur, 2010:116).

\begin{tabular}{ll}
\multicolumn{1}{c}{$r$} & \multicolumn{1}{c}{ İlişki } \\
$0,00-0,25$ & Çok Zayıf \\
$0,26-0,49$ & Zayıf \\
$0,50-0,69$ & Orta \\
$0,70-0,89$ & Yüksek \\
$0,90-1,00$ & Çok Yüksek
\end{tabular}

Korelasyon değerleri incelendiğinde, \%1 anlamlılık düzeyinde ilişkiler saptanmıştır. Buna göre ilişki düzeyi \%99 ihtimalle açıklanmıştır. Değerler pozitif olarak saptanmıştır. Buna göre ise aynı yönlü ilişkiler söz konusudur. İlişkinin düzeyi ile ilgili olarak yukarıdaki değer aralıklarına göre belirlenen yüksek, düşük gibi ifadelerle dereceler belirlenmiştir.

Korelasyon analizi tablosu incelendiğinde;

BN faktörü ile; GR faktörü arasında \%1 anlamlılık düzeyinde pozitif ve orta derecede $(0,613)$ bir ilişki vardır. BG faktörü arasında $\% 1$ anlamlılık düzeyinde pozitif ve orta derecede $(0,525)$ bir ilişki vardır. BR faktörü arasında $\% 1$ anlamlılık düzeyinde pozitif ve orta derecede $(0,631)$ bir ilişki vardır. $\mathrm{Bu}$ bağlamda Bilirkişi Nitelikleri arttıkça, Bilirkişi Görevlendirilmeleri, Bilirkişi Görevleri ve Bilirkişi Raporları da aynı yönde artacaktır. Dolayısıyla daha uygun görevler, raporlar ve görevlendirilmeler için nitelikli bilirkişilerden faydalanılması gerektiği söylenebilir. 
GR faktörü ile, BG faktörü arasında \%1 anlamlılık düzeyinde pozitif ve yüksek derecede $(0,720)$ bir ilişki vardır. BR faktörü arasında $\% 1$ anlamlılık düzeyinde pozitif ve yüksek derecede $(0,787)$ bir ilişki vardır. Bu bağlamda Bilirkişi Görevlendirilmeleri arttıkça, Bilirkişi Görevleri ve Bilirkişi Raporları da aynı yönde artacaktır. Dolayısıyla daha iyi görevler, raporlar için görevlendirilmelerin uygun yapılması gerektiği söylenebilir.

BG faktörü ile, BR faktörü arasında \%1 anlamlılık düzeyinde pozitif ve yüksek derecede $(0,717)$ bir ilişki vardır. Bu bağlamda Bilirkişi Görevleri arttıkça, Bilirkişi Raporları da aynı yönde artacaktır. Dolayısıyla daha iyi raporların iyi görevler sonucu ortaya çıktığ 1 söylenebilir.

\subsection{Türk Hukuk Sisteminde Bilirkişilik Müessesesinde Yaşanan Sorunların Varlığının Muhasebe Uzmanlık Alanı Çerçevesinde Araştırılması}

Ankette; katılımcıların, bilirkişilik müessesesinde yaşanan sorunların olmadığı, kimi zaman sorunların olduğu şeklinde dile getirilerek, katılım düzeyleri beş noktalı Likert ölçeğinde "kesinlikle katılıyorum" için "5", "kesinlikle katılmıyorum" için "1" olarak değerlendirilmiştir. Müessese ile ilgili sorunlar dört gruba (Bilirkişi Nitelikleri, Bilirkişi Görevlendirmeleri, Bilirkişilerin Görevleri, Bilirkişi Raporları) ayrılarak toplamda 37 yargı ifadesi ile değerlendirme yapılmış ve toplanan veriler normal dağılım gösterdiği için parametrik testler uygulanmıştır.

Bilirkişilik müessesesindeki sorunların değerlendirildiği anketteki bölümlerden BN, BG, BR'deki ifadeler hakimler tarafından değerlendirilmeye alınmış, GR'deki ifadeler ise SMMM'lerce değerlendirmeye alınmış olup, katılımcıların her bir soru için verdiği yanıtların her birinin ayrı ayrı ortalamaları ve grup ortalamaları tablolar oluşturularak verilmiştir. Ortalamaların yorumlanması aşağıdaki kriterlere göre yapılmıştır.

Sorulara verilecek en yüksek cevap 5 en düşük cevap 1 olduğundan aşağıdaki formül yoluyla ortalamalar anlamlandırılmaya çalışılmıştır. Grup aralığı değerleri $=(5-1) / 5=0,80$ olacaktır. Böylelikle ortalamalara yüklenecek anlamlar da şöyle olacaktır;

Katılma Derecesi

(1)

(2)

(3)

(4)
Derecelere İlișkin Aralıklar

$$
\begin{array}{ll}
1,00-1,80 & =\text { Kesinlikle Katılmıyorum } \\
1,81-2,60 & =\text { Kat1lmıyorum } \\
2,61-3,40 & =\text { Kararsızım } \\
3,41-4,20 & =\text { Kat1lyorum } \\
4,21-5,00 & =\text { Kesinlikle Kat1lyorum }
\end{array}
$$

Bilirkişilik müesesesi ile ilgili yaşanan sorunlara ilişkin belirlenen boyutlara göre toplanan verilerin analizi sonucu aşağıdaki bulgulara ulaşılmıştır. 
Tablo 5: Bilirkişilerin Nitelikleri İle İlgili Sorulara Hakimlerin Katılma Düzeyi

\begin{tabular}{|c|c|c|c|}
\hline & Ortalama & $\begin{array}{c}\text { Std. } \\
\text { Sapma }\end{array}$ & $\begin{array}{l}\text { Faktör } \\
\text { Ort. }\end{array}$ \\
\hline $\begin{array}{l}\text { BN1 Bilirkişiler, uyuşmazlık konusu ile ilgili ehil ve uzman } \\
\text { kişilerdir. }\end{array}$ & 4,64 &, 554 & \multirow{4}{*}{4,26} \\
\hline $\begin{array}{l}\text { BN2 Bilirkişilerin, davanın çözümüne yönelik hukuki becerileri } \\
\text { vardır. }\end{array}$ & 3,54 & ,883 & \\
\hline $\begin{array}{l}\text { BN3 Bilirkişilerin, davanın çözümüne yönelik teknik becerileri } \\
\text { vardır. }\end{array}$ & 4,45 & ,519 & \\
\hline $\begin{array}{l}\text { BN4 Bilirkişiler, tarafsız ve dürüst bir şekilde görevlerini icra } \\
\text { etmektedirler. }\end{array}$ & 4,40 &, 502 & \\
\hline
\end{tabular}

Tablo 5'de bilirkişilerin nitelikleri ile ilgili yargılara katılma düzeylerini belirtmeleri istenen hakimlerin verdikleri yanıtların ortalama değerleri gösterilmiştir. Tabloda yer alan sonuçlara göre; bilirkişilerin nitelikleri ile ilgili her hangi bir sorun tespit edilmemiştir. Bu grupta hakimlere, SMMM olarak kendilerine yardımcı olan bilirkişilerin nitelikleri ile ilgili sorunların olmadığını belirten ifadelere katılma düzeylerini belirtmeleri istenmiştir. Buna istinaden bu grubun ortalaması 4,26 ile kesinlikle katılma düzeyinde bir sonuç elde edilmiştir. Buna göre; muhasebeci bilirkişilerin

$\checkmark \quad$ ehil ve uzman,

$\checkmark \quad$ hukuki ve teknik becerileri olan kişilerden olduğu ve

görevlerini tarafsız ve dürüst bir şekilde ifa ettikleri söylenebilir.

Ancak bu grupta en düşük ortalama 3,54 ile muhasebeci bilirkişilerin hukuki becerilerinin olduğuna katılma düzeyi ile ilgili BN2 kodlu soruya aittir. En yüksek ortalama 4,64 ile muhasebeci bilirkişilerin uyuşmazlık konusu ile ilgili ehil ve uzman kişiler olduğuna katılma düzeyi ile ilgili BN1 kodlu soruya aittir. Muhasebeci bilirkişi yardımı gerektiğinde, konuyla ilgili ehil ve uzman kişiler bulunabildiği ancak söz konusu kişilerin hukuki becerilerinin olduğuna aynı düzeyde katılım olmadığı görülmüştür.

Ayrıca bulunan ortalama değerler test değeri "3" alınarak tek örneklem t testi analizi yapılmıştır. Analiz sonucu tablo 6'da aşağıdaki gibidir:

Tablo 6: Bilirkişi Nitelikleri İle İlgili Bulgulara Tek Örneklem T Testi Analizi

\begin{tabular}{|l|c|c|c|c|c|c|}
\hline DEĞişKENLER & $\mathbf{N}$ & Mean & $\begin{array}{c}\text { Std. } \\
\text { Deviation }\end{array}$ & $\mathbf{T}$ & Sig. & $\begin{array}{c}\text { Ortalama } \\
\text { Farklılıkları }\end{array}$ \\
\hline $\begin{array}{c}\text { BN1 Bilirkişiler, uyuşmazlık konusu } \\
\text { ile ilgili ehil ve uzman } \\
\text { kişilerdir. }\end{array}$ & 190 & 4,64 &, 554 & 40,749 &, $000^{* *}$ & 1,637 \\
\hline $\begin{array}{c}\text { BN2 Bilirkişilerin, davanın } \\
\text { çözümüne yönelik hukuki } \\
\text { becerileri vardır. }\end{array}$ & 190 & 3,54 &, 883 & 8,384 &, $000^{* *}$ & 0,537 \\
\hline BN3 Bilirkişilerin, davanın & 190 & 4,45 &, 519 & 38,416 &, $000^{* *}$ & 1,447 \\
\hline
\end{tabular}




\begin{tabular}{|c|c|c|c|c|c|c|}
\hline $\begin{array}{l}\text { çözümüne yönelik teknik } \\
\text { becerileri vardır. }\end{array}$ & & & & & & \\
\hline $\begin{array}{l}\text { BN4 Bilirkişiler, tarafsı ve dürüst } \\
\text { bir şekilde görevlerini icra } \\
\text { etmektedirler. }\end{array}$ & 190 & 4,40 &, 502 & 38,453 &, $000^{* *}$ & 1,400 \\
\hline **p< 0,01
\end{tabular}

Yapılan analiz sonucu "H1: BN ile ortalama değer 3 arasında anlamlı bir ilişki vardır" şeklinde kurulan hipotez kabul edilmiştir. Tablodaki ortalama değerlerin hepsinin \%1 anlamlılık seviyesinde 3'ten büyük olması sebebiyle bilirkişilerin nitelikleri ile ilgili sorunların olmadığı sonucu elde edilmiştir.

Tablo 7'de bilirkişilerin görevlendirilmeleri ile ilgili yargılara katılma düzeylerini belirtmeleri istenen SMMM'lerin verdikleri yanıtların ortalama değerleri gösterilmiştir.

Tablo 7: Bilirkişilerin Görevlendirilmeleri İle İlgili Sorulara SMMM'lerin Katılma Düzeyi

\begin{tabular}{|c|c|c|c|}
\hline & Ortalama & \begin{tabular}{c|c} 
Std. \\
Sapma
\end{tabular} & $\begin{array}{c}\text { Faktör } \\
\text { Ort. }\end{array}$ \\
\hline GR1 Uyuşmazlıkla ilgili dava dosyası yetkili adli makamlarca etraflıca incelenmektedir. & 3,59 & ,940 & \multirow{12}{*}{3,26} \\
\hline GR2 Uyuşmazlıkla ilgili hukukî ve genel bilgiler için bilirkişiye başvurulma-mak-tadır. & 3,43 & ,957 & \\
\hline $\begin{array}{l}\text { GR3 Uyuşmazlığın çözümü teknik ve özel bilgi gerektiriyorsa bilirkişiye } \\
\text { başvurulmaktadır }\end{array}$ & 4,06 &, 522 & \\
\hline $\begin{array}{l}\text { GR4 Aynı uzmanlık alanında, sürekli olarak aynı kişiler bilirkişi olarak görevlendirilme- } \\
\text { mektedir. }\end{array}$ & 3,37 & 1,040 & \\
\hline $\begin{array}{l}\text { GR5 Önceden, uyuşmazlık konusu ile ilgili bilirkişi olarak görevlendirilecek kişi veya } \\
\text { kişilerle görüş alış-verişi yapılmaktadır }\end{array}$ & 2,98 & 1,066 & \\
\hline GR6 Bilirkişiye sorulacak sorular açık ve ayrıntılı olarak önceden belirlenmektedir. & 3,55 & 1,003 & \\
\hline GR7 Bilirkişinin görev alanının çevresi, açık ve kesin bir dille çizilmektedir. & 3,67 & ,897 & \\
\hline $\begin{array}{l}\text { GR8 Uyuşmazlık konusu ile ilgili gerekli tüm bilgi ve belgeler, bilirkişilere teslim } \\
\text { edilmektedir. }\end{array}$ & 3,73 & ,878 & \\
\hline GR9 Bilirkişilerin hukukî statüsü, yetkileri ve yükümlülükleri mevzuatta belirtilmektedir. & 3,98 & ,515 & \\
\hline $\begin{array}{l}\text { GR10 Gerçeğe aykırı bilirkişilik suçundan dolayı, suçlu sayılan bilirkişilere cezai } \\
\text { yaptırımlar uygulanmaktadır. }\end{array}$ & 3,60 & 913 & \\
\hline GR11 Görevlendirilen bilirkişilere yemin verdirilmektedir. & 4,23 & ,419 & \\
\hline GR12 Bilirkişi ücretleri işin niteliğine göre belirlenmektedir. & 3,63 & ,956 & \\
\hline
\end{tabular}

Tabloda yer alan sonuçlara göre; bilirkişilerin görevlendirilmeleri hususunda her hangi bir sorun tespit edilmemiştir. SMMM'lere bilirkişi görevlendirmeleri esnasında sorunların olmadığını belirten cümleler kullanılarak katılma düzeylerini belirtmeleri istenmiştir, buna 
istinaden bu grubun ortalaması 3,26 ile katılma düzeyinde bir sonuç elde edilmiştir. Buna göre;

$\checkmark \quad$ dosyanın bilirkişiye, etraflıca incelenerek tevdi edildiği,

hukuki ve genel bilgiler için bile bilirkişilere müracaat edilmediği, teknik ve özel bilgiler için bilirkişiye başvurulduğu,

$\checkmark \quad$ sürekli aynı kişilerin bilirkişi olarak seçilmediği,
$\checkmark \quad$ görevlendirme yapılmadan önce yardımı düşünülen bilirkişilerle görüş alışverişi yapıldı̆̆ 1 ,
$\checkmark \quad$ bilirkişiye sorulacak soruların açık ve ayrıntılı olarak belirlendiği,
$\checkmark \quad$ bilirkişilerin görev alanlarının kesin olarak belirlendiği,
$\checkmark \quad$ konu ile ilgili bütün bilgi ve belgelerin bilirkişilere teslim edildiği,
$\checkmark \quad$ mevzuatta hukuki statü- yetki ve yükümlülüklerin tanımlandığı,
$\checkmark \quad$ gerçeğe aykırı bilirkişilik suçundan dolayı cezai yaptırımların uygulandığı,
$\checkmark \quad$ yemin mekanizmasının işlediği,
$\checkmark \quad$ ücretin işin niteliğine uygun olarak belirlendiği söylenebilir.

Ancak bu grupta en düşük ortalama 2,98 ile uyuşmazlık konusunun bilirkişi olarak görevlendirilecek kişilerle görüş alış-verişi yapıldığına katılma düzeyi ile ilgili GR5 kodlu soruya aittir. En yüksek ortalama 4,23 ile görevlendirilen bilirkişilere yemin verdirildiğine katılma düzeyi ile ilgili GR11 kodlu soruya aittir. Konuyla ilgili yemin mekanizmasının işlediği ve dolayısıyla vicdani baskının oluştuğu söylenebilir. Ancak görüş-alışverişi yapılarak görevlendirmelerin yapıldığı hususuna aynı düzeyde katılım olmamıştır.

Tablo 8'de verilen yanıtların ortalama değerleri, test değeri “ 3 ” alınarak tek örneklem t testi analizi sonuçları gösterilmiştir.

Tablo 8: Bilirkişi Görevlendirilmeleri İle İlgili Bulgulara Tek Örneklem T Testi Analizi

\begin{tabular}{|c|c|c|c|c|c|c|}
\hline DEĞIŞKENLER & $\mathbf{N}$ & Mean & \begin{tabular}{c|c|} 
Std. \\
Deviation
\end{tabular} & $\mathbf{T}$ & Sig. & \begin{tabular}{|c|} 
Ortalama \\
Farklılıkları
\end{tabular} \\
\hline $\begin{array}{l}\text { GR1 Uyuşmazlıkla ilgili dava dosyası yetkili adli makamlarca } \\
\text { etraflıca incelenmektedir. }\end{array}$ & 204 & 3,59 & ,940 & 8,937 &, $000 * *$ & 0,588 \\
\hline $\begin{array}{l}\text { GR2 Uyuşmazlıkla ilgili hukukî ve genel bilgiler için } \\
\text { bilirkişiye başvurulma-mak-tadır. }\end{array}$ & 204 & 3,43 & ,957 & 6,365 &, $000 * *$ & 0,426 \\
\hline $\begin{array}{l}\text { GR3 Uyuşmazlığın çözümü teknik ve özel bilgi gerektiriyorsa } \\
\text { bilirkişiye başvurulmaktadır }\end{array}$ & 204 & 4,06 &, 522 & 28,977 &, $000 * *$ & 1,059 \\
\hline $\begin{array}{l}\text { GR4 Aynı uzmanlık alanında, sürekli olarak aynı kişiler } \\
\text { bilirkişi olarak görevlendirilme-mektedir. }\end{array}$ & 204 & 3,37 & 1,040 & 5,115 &, $000 * *$ & 0,373 \\
\hline $\begin{array}{l}\text { GR5 Önceden, uyuşmazlık konusu ile ilgili bilirkişi olarak } \\
\text { görevlendirilecek kişi veya kişilerle görüş alış-verişi } \\
\text { yapılmaktadır }\end{array}$ & 204 & 2,98 & 1,066 &,- 328 & ,743 & $-0,025$ \\
\hline $\begin{array}{l}\text { GR6 Bilirkişiye sorulacak sorular açık ve ayrıntılı olarak } \\
\text { önceden belirlenmektedir. }\end{array}$ & 204 & 3,55 & 1,003 & 7,884 &, $000 * *$ & 0,554 \\
\hline
\end{tabular}




\begin{tabular}{|c|c|c|c|c|c|c|}
\hline $\begin{array}{c}\text { GR7 Bilirkişinin görev alanının çevresi, açık ve kesin bir dille } \\
\text { çizilmektedir. }\end{array}$ & 204 & 3,67 &, 897 & 10,615 &, $000^{* *}$ & 0,667 \\
\hline $\begin{array}{c}\text { GR8 Uyuşmazlık konusu ile ilgili gerekli tüm bilgi ve } \\
\text { belgeler, bilirkişilere teslim edilmektedir. }\end{array}$ & 204 & 3,73 &, 878 & 11,797 &, $000^{* *}$ & 0,725 \\
\hline $\begin{array}{c}\text { GR9 Bilirkişilerin hukuki statüsü, yetkileri ve yükümlülükleri } \\
\text { mevzuatta belirtilmektedir. }\end{array}$ & 204 & 3,98 &, 515 & 27,170 &, $000^{* *}$ & 0,980 \\
\hline $\begin{array}{c}\text { GR10 Gerçeğe aykırı bilirkişilik suçundan dolayı, suçlu } \\
\text { sayılan bilirkişilere cezai yaptırımlar uygulanmaktadır. }\end{array}$ & 204 & 3,60 &, 913 & 9,360 &, $000^{* *}$ & 0,598 \\
\hline GR11 Görevlendirilen bilirkişilere yemin verdirilmektedir. & 204 & $\mathbf{4 , 2 3}$ &, 419 & 41,781 &, $000^{* *}$ & 1,225 \\
\hline GR12 Bilirkişi ücretleri işin niteliğine göre belirlenmektedir. & 204 & 3,63 &, 956 & 9,370 &, $000^{* *}$ & 0,627 \\
\hline
\end{tabular}

$* * \mathrm{p}<0,01$

Yapılan analiz sonucu "H2: GR ile ortalama değer 3 arasında anlamlı bir ilişki vardır" şeklinde kurulan hipotez kabul edilmiştir. GR 5 maddesindeki ifade ile ortalama değer arasında anlamlı bir ilişki yoktur. Tablodaki ortalama değerlerin GR 5 hariç, hepsinin \%1 anlamlılık seviyesinde 3 'ten büyük olması sebebiyle bilirkişilerin görevlendirilmeleri ile ilgili sorunların olmadığ 1 sonucu elde edilmiştir.

Tablo 9'da bilirkişilerin görevlerini ifa etmeleri ile ilgili yargılara katılma düzeylerini belirtmeleri istenen hakimlerin verdikleri yanıtların ortalama değerleri gösterilmiştir.

Tablo 9: Bilirkişilerin Görevlerini Yerine Getirmeleri İle İlgili Sorulara Hakimlerin Katılma Düzeyi

\begin{tabular}{|c|c|c|c|}
\hline & Ortalama & $\begin{array}{c}\text { Std. } \\
\text { Sapma }\end{array}$ & $\begin{array}{c}\text { Faktör } \\
\text { Ort. }\end{array}$ \\
\hline $\begin{array}{c}\text { BG1 Bilirkişi, sorunun kendi uzmanlık alanına girmediğini ya da özel bilgileri } \\
\text { gerektirdiğini düşündüğünde durumu kendisini görevlendiren makama } \\
\text { bildirmektedir. }\end{array}$ & $\mathbf{3 , 9 5}$ &, 939 & \\
\hline $\begin{array}{c}\text { BG2 Bilirkişiler, kurul teşkil edecek şekilde görevlendirilmeleri durumunda, } \\
\text { kurul şeklinde çalışmaya özen göstermektedirler. }\end{array}$ & $\mathbf{4 , 3 2}$ &, 587 & \multirow{2}{*}{4,28} \\
\hline $\begin{array}{c}\text { BG3 Kurul içinde görevlendirilen farklı bilirkişiler, görüş farklılıklarını, ortak } \\
\text { hazırlanan rapora muhalefet şerhi düşerek belirtmektedirler. }\end{array}$ & 4,27 &, 503 &, 546 \\
\hline $\begin{array}{c}\text { BG4 Bilirkişiler, görevlendirme yazısında kendilerine tanınan süre içerisinde } \\
\text { rapor ve eklerini mahkemeye göndermektedirler. }\end{array}$ & 4,26 &, & \\
\hline
\end{tabular}

Tabloda yer alan sonuçlara göre; bilirkişilerin görevlerini ifa ederken her hangi bir sorun tespit edilmemiştir. Hakimlere bilirkişilerin görevlerini ifa ederken sorunların olmadığını belirten cümleler kullanılarak katılma düzeylerini belirtmeleri istenmiş, buna istinaden bu grubun ortalaması 4,28 ile katılma düzeyinde bir sonuç elde edilmiştir. Buna göre;

bilirkişilik yapanların uyuşmazlığın kendi uzmanlık alanına girmediğini düşündüklerinde, durumu yetkili makamlara bildirdikleri,

kurul şeklinde görevlendirmelerde kurul şeklinde çalışmaya özen gösterdikleri, 
$\checkmark$ görüş farklılıklarını ortak hazırlanan rapora muhalefet şerhi düşerek belirttikleri, raporları ve eklerini tanınan süre zarfinda mahkemeye teslim ettikleri söylenebilir.

Ancak bu grupta en düşük ortalama 3,95 ile sorunun kendi uzmanlık alanına girmediğini ya da özel bilgileri gerektirdiğini düşündüğünde durumu kendisini görevlendiren makama bildirdiğine katılma düzeyi ile ilgili BG1 kodlu soruya aittir. En yüksek ortalama 4,32 ile kurul teşkil edecek şekilde görevlendirilmeleri durumunda, kurul şeklinde çalışmaya özen gösterdiklerine katılma düzeyi ile ilgili BG2 kodlu soruya aittir. Konuyla ilgili olarak; ekip çalışmalarında özenle görevlerini yapmaları hususunda katılım yüksek olurken uyuşmazlığın kendi uzmanlık alanıyla ilgili olmadığında durumu bildirme hususuna aynı düzeyde katılım olmamıştır.

Tablo 10'da verilen yanıtların ortalama değerleri, test değeri “3” alınarak tek örneklem $\mathrm{t}$ testi analizi sonuçları gösterilmiştir.

Tablo 10: Bilirkişi Görevlerini Yerine Getirmeleri İle İlgili Bulgulara Tek Örneklem T Testi Analizi

\begin{tabular}{|c|c|c|c|c|c|c|}
\hline DEĞişKENLER & $\mathbf{N}$ & Mean & $\begin{array}{c}\text { Std. } \\
\text { Deviation }\end{array}$ & $\mathbf{T}$ & Sig. & $\begin{array}{c}\text { Ortalama } \\
\text { Farklılıkları }\end{array}$ \\
\hline $\begin{array}{c}\text { BG1 Bilirkişi, sorunun kendi uzmanlık alanına } \\
\text { girmediğini ya da özel bilgileri gerektirdiğini } \\
\text { düşündüğünde durumu kendisini görevlendiren } \\
\text { makama bildirmektedir. }\end{array}$ & 190 & $\mathbf{3 , 9 5}$ &, 939 & 13,987 &, $000^{* *}$ & 0,953 \\
\hline $\begin{array}{c}\text { BG2 Bilirkişiler, kurul teşkil edecek şekilde } \\
\text { görevlendirilmeleri durumunda, kurul şeklinde } \\
\text { çalışmaya özen göstermektedirler. }\end{array}$ & 190 & $\mathbf{4 , 3 2}$ &, 587 & 30,914 &, $000^{* *}$ & 1,316 \\
\hline $\begin{array}{c}\text { BG3 Kurul içinde görevlendirilen farklı bilirkişiler, } \\
\text { görüş farklılıklarını, ortak hazırlanan rapora } \\
\text { muhalefet şerhi düşerek belirtmektedirler. }\end{array}$ & 190 & 4,27 &, 503 & 34,922 &, $000^{* *}$ & 1,274 \\
\hline $\begin{array}{c}\text { BG4 Bilirkişiler, görevlendirme yazısında } \\
\text { kendilerine tanınan süre içerisinde rapor ve } \\
\text { eklerini mahkemeye göndermektedirler. }\end{array}$ & 190 & 4,26 &, 546 & 31,751 &, $000^{* *}$ & 1,258 \\
\hline
\end{tabular}

$* * \mathrm{p}<0,01$

Yapılan analiz sonucu " $\mathrm{H}_{3}$ : BG ile ortalama değer 3 arasında anlamlı bir ilişki vardır" şeklinde kurulan hipotez kabul edilmiştir. Tablodaki ortalama değerlerin hepsinin \% 1 anlamlılık seviyesinde 3 'ten büyük olması sebebiyle bilirkişilerin faaliyetleriyle ilgili sorunların olmadığ 1 sonucu elde edilmiştir.

Tablo 11 'de bilirkişilerin hazırladıkları raporlar ile ilgili yargılara katılma düzeylerini belirtmeleri istenen hakimlerin verdikleri yanıtların ortalama değerleri gösterilmiştir. 
Tablo 11: Bilirkişilerin Hazırladıkları Raporlar İle İlgili Sorulara Hakimlerin Katılma Düzeyi

\begin{tabular}{|c|c|c|c|}
\hline & Ortalama & $\begin{array}{c}\text { Std. } \\
\text { Sapma }\end{array}$ & $\begin{array}{l}\text { Faktör } \\
\text { Ort. }\end{array}$ \\
\hline BR1 Bilirkişi raporları, başkalarına tanzim ettirilme-mek-tedir. & 4,26 & ,495 & \multirow{17}{*}{4,21} \\
\hline $\begin{array}{l}\text { BR2 Bilirkişi raporları, kabul edilebilir, makul ve gerçekçi bir gerekçeye } \\
\text { davandırılmaktadır. }\end{array}$ & 4,17 & ,389 & \\
\hline BR3 Bilirkişi raporları, şekil açısından önemli eksiklik veya yanlışlık içerme-mek-tedir. & 4,19 & ,470 & \\
\hline BR4 Bilirkişi raporlarında, hatalar, hukukî kavram eksiklikleri ve yetersizlikler görülme-mek-tedir. & 3,86 & 1,000 & \\
\hline BR5 Bilirkişiler, gerçeği saklayan veya çarpıtan raporlar düzenleme-mek-tedirler. & 4,30 & ,482 & \\
\hline BR6 Bilirkişi raporları, gerekli inceleme ve araştırma yapılmadan oluşturulma-mak-tadır. & 4,24 & ,516 & \\
\hline BR7 Bilirkişiler, teknik konuları açık bir dille ve öğretici bir biçimde açıklamaktadırlar. & 4,23 & ,459 & \\
\hline BR8 Bilirkişi raporlarında yer alan açıklamalar, bilirkişinin uzmanlık alanıyla sınırlıdır. & 4,28 & 464 & \\
\hline BR9 Bilirkişi raporları, her somut olaya dayalı olarak ayrı ve orijinal olarak hazırlanmaktadır. & 4,24 & ,476 & \\
\hline BR10 Bilirkişi raporları, bilirkişinin kendi alanında bilgi ile basit ve kesin yargılar içermektedir. & 4,24 & 465 & \\
\hline BR11 Bilirkişi raporları, açık-seçik ve olabildiğince kısadır. & 3,98 & ,957 & \\
\hline BR12 Bilirkişiler, bilinmeyen hususları da raporlarında açıkça belirtmektedirler. & 4,25 & ,524 & \\
\hline BR13 Anlaşılmayan ve eksik raporlardan dolayı ek raporlar istenmektedir. & 4,32 & ,466 & \\
\hline BR14 Hatalı raporlardan dolayı yeni bilirkişiler görevlendirilmektedir. & 4,20 & 427 & \\
\hline BR15 Açıklamalarda bulunmak üzere bilirkişiler, duruşmalara çağrılmaktadırlar. & 2,69 & 1,201 & \\
\hline BR16 Bilirkişi raporu, duruşmadan önce taraflara tebliğ edilmektedir. & 4,26 & 465 & \\
\hline BR17 Bilirkişi raporunun aksine karar veril-me-mek-tedir. & 4,26 & ,498 & \\
\hline
\end{tabular}

Tabloda yer alan sonuçlara göre; bilirkişilerin hazırladıkları raporlar ile ilgili her hangi bir sorun tespit edilmemiştir. Katılımcılara söz konusu sorunların olmadığını belirten cümleler kullanılarak ayrıca bazı sorunlar ifade edilerek katılma düzeylerini belirtmeleri istenmiş, buna istinaden bu grubun ortalamas1 4,21 ile katılma düzeyinde bir sonuç elde edilmiştir. Buna göre;

raporların başkalarına tanzim ettirilmediği,

gerekçesiz raporlar hazırlanmadığı,

raporların şekil açısından önemli eksiklik veya yanlışlıklar içermediği,

raporlarda hukuki kavram yetersizliğinin olmadığ

gerçeği saklayan veya çarpıtan raporlar hazırlanmadığı,

raporların gerekli araştırma ve incelemeden sonra hazırlandığı,

raporlarda teknik konuların açık bir dille öğretici biçimde ifade edildiği,

raporlarda yer alan açıklamaların bilirkişilerin uzmanlık alanıyla sınırlı olduğu, her somut olaya dayalı olarak ayrı ve orijinal raporlar hazırlandığı, raporların bilirkişilerin uzmanlık alanında bilgi ile basit ve kesin yargılar içerdiği, 
$\checkmark \quad$ raporların yeterince açık-seçik ve kısa olduğu,

$\checkmark \quad$ raporlarda bilinmeyen hususların belirtildiği,

raporun duruşmadan önce tebliğ edildiği olumlu manada söylenebilirken,

- bilirkişilerin hazırladıkları anlaşılmayan ve eksik raporlardan dolayı ek raporlar istendiği

- hatalı raporlardan dolayı aynı uyuşmazlık konusu için yeni bilirkişilerin görevlendirildiği,

- açıklamalarda bulunmak üzere bilirkişilerin duruşmalara çağrılmadığı,

- raporun aksine karar verilmediği gibi sakıncalı durumların tespit edildiği söylenebilir.

$\mathrm{Bu}$ grupta en düşük ortalama 2,69 ile açıklamalarda bulunmak üzere bilirkişilerin duruşmalara çağrıldığına katılma düzeyi ile ilgili BR15 kodlu soruya aittir. En yüksek ortalama 4,32 ile hatalı raporlardan dolayı yeni bilirkişilerin görevlendirilmesine katılma düzeyi ile ilgili BR 14 kodlu soruya aittir. Ülkemizde bilirkişiler sadece yazılı raporları ile mahkemeye yardımcı olmakta, açıklamalarda bulunmak üzere duruşmalara çağrılmamaktadır. Dolayısıyla bu durumu ifade eden maddeye katılım düzeyi düşüktür. Hatalı raporlardan dolayı yeni bilirkişi görevlendirilmesi hususuna ise yüksek düzeyde katılım söz konusudur.

Tablo 12'de verilen yanıtların ortalama değerleri, test değeri "3" alınarak tek örneklem $\mathrm{t}$ testi analizi sonuçları gösterilmiştir.

Tablo 12: Bilirkişilerin Hazırladıkları Raporlar İle İlgili Bulgulara Tek Örneklem T Testi Analizi

\begin{tabular}{|l|c|c|c|c|c|c|}
\hline DEĞíşKENLER & $\mathbf{N}$ & Mean & $\begin{array}{c}\text { Std. } \\
\text { Deviation }\end{array}$ & T & Sig. & $\begin{array}{c}\text { Ortalama } \\
\text { Farklılıkları }\end{array}$ \\
\hline $\begin{array}{l}\text { BR1 Bilirkişi raporları, başkalarına tanzim ettirilme- } \\
\text { mek-tedir. }\end{array}$ & 190 & 4,26 &, 495 & 35,008 &, $000^{* *}$ & 1,258 \\
\hline $\begin{array}{c}\text { BR2 Bilirkişi raporları, kabul edilebilir, makul ve } \\
\text { gerçekçi bir gerekçeye dayandırılmaktadır. }\end{array}$ & 190 & 4,17 &, 389 & 41,395 &, $000^{* *}$ & 1,168 \\
\hline $\begin{array}{c}\text { BR3 Bilirkişi raporları, şekil açısından önemli } \\
\text { eksiklik veya yanlş̧lı içerme-mek-tedir. }\end{array}$ & 190 & 4,19 &, 470 & 35,020 &, $000^{* *}$ & 1,195 \\
\hline $\begin{array}{c}\text { BR4 Bilirkişi raporlarında, hatalar, hukukî kavram } \\
\text { eksiklikleri ve yetersizlikler görülme-mek-tedir. }\end{array}$ & 190 & 3,86 & 1,000 & 11,820 &, $000^{* *}$ & 0,858 \\
\hline $\begin{array}{c}\text { BR5 Bilirkişiler, gerçeği saklayan veya çarpıtan } \\
\text { raporlar düzenleme-mek-tedirler. }\end{array}$ & 190 & $\mathbf{4 , 3 0}$ &, 482 & 37,181 &, $000^{* *}$ & 1,300 \\
\hline $\begin{array}{c}\text { BR6 Bilirkişi raporları, gerekli inceleme ve araştırma } \\
\text { yap1lmadan oluşturulma-mak-tadır. }\end{array}$ & 190 & 4,24 &, 516 & 33,034 &, $000^{* *}$ & 1,237 \\
\hline $\begin{array}{c}\text { BR7 Bilirkişiler, teknik konuları açı bir dille ve } \\
\text { öğretici bir biçimde açıklamaktadırlar. }\end{array}$ & 190 & 4,23 &, 459 & 36,989 &, $000^{* *}$ & 1,232 \\
\hline $\begin{array}{c}\text { BR8 Bilirkişi raporlarında yer alan açıklamalar, } \\
\text { bilirkişinin uzmanlık alanıyla sınırlıdır. }\end{array}$ & 190 & 4,28 &, 464 & 38,168 &, $000^{* *}$ & 1,284 \\
\hline $\begin{array}{c}\text { BR9 Bilirkişi raporları, her somut olaya dayalı olarak } \\
\text { ayr1 ve orijinal olarak hazırlanmaktadır. }\end{array}$ & 190 & 4,24 &, 476 & 35,952 &, $000^{* *}$ & 1,242 \\
\hline $\begin{array}{c}\text { BR10 Bilirkişi raporları, bilirkişinin kendi alanında } \\
\text { bilgi ile basit ve kesin yargılar içermektedir. }\end{array}$ & 190 & 4,24 &, 465 & 36,821 &, $000^{* *}$ & 1,242 \\
\hline
\end{tabular}




\begin{tabular}{|l|c|c|c|c|c|c|}
\hline $\begin{array}{l}\text { BR11 Bilirkişi raporları, açık-seçik ve olabildiğince } \\
\text { kısadır. }\end{array}$ & 190 & 3,98 &, 957 & 14,182 &, $000^{* *}$ & 0,984 \\
\hline $\begin{array}{l}\text { BR12 Bilirkşiler, bilinmeyen hususları da } \\
\text { raporlarında açıç̧a belirtmektedirler. }\end{array}$ & 190 & 4,25 &, 524 & 32,958 &, $000^{* *}$ & 1,253 \\
\hline $\begin{array}{l}\text { BR13 Anlaş1lmayan ve eksik raporlardan dolayı ek } \\
\text { raporlar istenmektedir. }\end{array}$ & 190 & 4,32 &, 466 & 38,916 &, $000^{* *}$ & 1,316 \\
\hline $\begin{array}{l}\text { BR14 Hatalı raporlardan dolayı yeni bilirkişiler } \\
\text { görevlendirilmektedir. }\end{array}$ & 190 & 4,20 &, 427 & 38,771 &, $000^{* *}$ & 1,200 \\
\hline $\begin{array}{l}\text { BR15 Açılkamalarda bulunmak üzere bilirkişiler, } \\
\text { duruşmalara çağrılmaktadırlar. }\end{array}$ & 190 & $\mathbf{2 , 6 9}$ & 1,201 & $-3,564$ &, $000^{* *}$ & $-0,311$ \\
\hline $\begin{array}{l}\text { BR16 Bilirkişi raporu, duruşmadan önce taraflara } \\
\text { tebliğ edilmektedir. }\end{array}$ & 190 & 4,26 &, 465 & 37,455 &, $000^{* *}$ & 1,263 \\
\hline $\begin{array}{c}\text { BR17 Bilirkişi raporunun aksine karar veril-me-mek- } \\
\text { tedir. }\end{array}$ & 190 & 4,26 &, 498 & 34,974 &, $000^{* *}$ & 1,263 \\
\hline$* *$ p< 0,01
\end{tabular}

Yapılan analiz sonucu "H3: BR ile ortalama değer 3 arasında anlamlı bir ilişki vardır" şeklinde kurulan hipotez kabul edilmiştir. BR 15 maddesindeki ifade ile ortalama değer arasında anlamlı bir ilişki yoktur. Tablodaki ortalama değerlerin BR 15 hariç, hepsinin \%1 anlamlılık seviyesinde 3'ten büyük olması sebebiyle hazırlanan raporlarla ilgili sorunların olmadığ 1 sonucu elde edilmiştir. Ancak bazı ifadelerde BR 13, 14, 17'de ortalamaların 3 'ten büyük olması ile sorunlara işaret eden ifadelere katılım düzeyi gösterilmiştir. Bu sebeple söz konusu ifadeler ve ortalamanın 3'ten küçük olduğu BR 15 ifadesi raporlama ile ilgili sorunlara işaret etmektedir.

\section{SONUÇ}

Mahkemeye intikal etmiş, muhasebe bilimi ile ilgili bilgi içeren sorunları, hakimin hukuk ve genel bilgisi ile çözümleyemeyeceği düşünüldüğünde, mevcut sistem çerçevesinde bilirkişilerden yardım alabileceği bilinmektedir. Bu bağlamda muhasebe bilgisine sahip kişilerden bilirkişi olarak yardım alınmaktadır. Bu kapsamda SMMM, YMM, söz konusu alandaki öğretim üyeleri bilirkişi olarak hakime yardımcı olmaktadır. Ancak bilirkişilik müessesesinde bir takım sorunların olduğu bilinmektedir.

Çalışmada, bilirkişilik müessesesinde yaşanan sorunların muhasebeci bilirkişileri kapsayıp kapsamadığı araştırılmıştır. Araştırma, anket sorularının oluşturularak muhasebeci bilirkişi yardımı alan hakimlere ve bilirkişilik yapan SMMM'lere uygulanması suretiyle verilerin toplanması ve SPSS ile değerlendirilmesi ile yürütülmüştür.

Anketlerin uygulanmasıyla derlenen verilerin değerlendirilmesi sonucu, ortaya çıkan bulgular özetle;

Bilirkişilik müessesesinde yaşanan problemler mali müşavir ve hakimlerin değerlendirmesi sonucu SMMM olarak bilirkişilik yapanları kapsamamaktadır.

Hazırlanan raporlara itirazın dava taraflarınca sık uygulanması ile ya da duruşmalara açıklamalarda bulunmak üzere katılımı sağlanmayan bilirkişilerden dolayı raporun anlaşılır kılınmaması, önemli hususlara dikkat çekilmemesi, raporun yeterince değerlendirmeye alınamaması gibi sakıncaları da beraberinde taşıyan bir uygulama ile 
anlaşılmayan, eksik veya hatalı raporlardan dolayı ek raporların istenmesi ve yeni bilirkişi incelemelerinin yaptırılması söz konusudur. Bu tür uygulamalar uyuşmazlığın çözümünü sürüncemede bırakmakta, bilirkişilik müessesesinin bir ileri boyuta taşınması gerektiği hususuna dikkat çekmektedir.

$>$ Hazırlanan rapora aksi karar verilmemesi söz konusudur. Konu ile ilgili doktrin, Yargıtay ve Danıştay'ın tutumu farklılaşmakla ${ }^{11}$ beraber böyle bir uygulamanın hakimin bağımsızlı̆ğ ilkesine ters düşmesi ve bilirkişiyi hakim yerine koyması sebebiyle sakıncalarının olduğu düşünülmektedir. $\mathrm{Bu}$ tür uygulamalar bilirkişilik müessesesini suiistimale açık bırakarak adalete olan güvenin önemini yitirmesine sebep olmaktadır.

Sonuçlarla ilgili olarak, anketler uygulanırken yapılan yüz yüze mülakatlar neticesinde hakimlerin genel anlamda muhasebeci bilirkişilerden memnun oldukları söylemleriyle karşılaşılmıştır. Ayrıca bilirkişilik müessesesinin sorunlarını değerlendirmeye yönelik oluşturulan boyutlardan, Bilirkişi Nitelikleri, Bilirkişi Görevleri ve Bilirkişi Raporları kısımları ile ilgili hakimlerin değerlendirmeleri ölçülmüş, ortalamalar sırasıyla; 4,26 - 4,28 ve 4,21 şeklinde olmuştur. Elde edilen bulgular mülakatlardaki söylemlerle benzer sonuçlardır.

Ancak raporlama aşamasında problemli uygulamalar söz konusudur. Bilirkişi Raporları kısmında BR 13, 14, 15 ve 17 ile ölçülen sorun ifade eden ve edecek bazı uygulamalar, ülkemizde uygulanan bilirkişilik müessesesinin daha kapsamlı ve yetkin hizmet için bir ileri boyuta taşınması gerektiğini ortaya koymuştur.

Yeni ve ek bilirkişi incelemeleri yaptırmanın yargı süreci ve kalitesine olumsuz etkisinin mahkemelerde aktif rol üstlenen muhasebeciler ile mesleğin modülasyonu olarak değil de bizzat görevleri arasında söz konusu hizmetleri vermesi ile giderileceği düşünülmektedir. Ayrıca bu yolla hakimin okuduğu rapora bağlı kalarak karar vermesinin de önüne geçilerek mahkeme esnasında yapılan açıklamalar ile raporun hakimce değerlendirme süzgecinden geçirilmesi de sağlanmış olacaktır. Çözüm önerisi olarak mahkemede aktif rol üstlenen, çalışmalarıyla fark yaratacak adli muhasebecilik olarak isimlendirilen yurt dışında faal olan muhasebenin yeni alt dalının daha etkin olacağı düşünülmektedir.

\section{KAYNAKLAR}

Adalet Bakanlı̆̆ (2010), "Bilirkişilik Sistemindeki Sorunların Tespiti ile Çözüm Önerisi Geliştirilmesi ile İlgili İnceleme Raporu”, Rapor No: 2010/4.

Adalet Bakanlığı Avrupa Birliği Genel Müdürlüğü (2010), "Yargıllamada Bilirkişilik Müessesesi”.

\footnotetext{
${ }^{11}$ HMK m.282: "hakim bilirkişinin oy ve görüşünü̈ diğer delillerle birlikte serbestçe değerlendirir” kanun hükmü değiş̧ik şekillerde yorumlanarak bilirkişinin raporunun bağlayıcıllğı hususunda doktrin, Yargıtay ve Danıştay'ın tutumları farklıdır. Söz konusu kanun hükmü, yetersiz bilirkişi raporları ile karşılaşıldığında, ek veya yeni bilirkişi incelemeleri yaptırılması şeklinde yorumlandığı gibi, yeniden inceleme yaptırmaya gerek kalmaksızın hakimde yeterince kanaat oluştuğunda farklı yönde kararlar alınabileceği şeklinde de yorumlanmıştır.
} 
<http://www.abgm.adalet.gov.tr/pdf/bilirki\%C5\%9Fi\%20rapor\%2014.2.2011.pdf> (09.04.2014)

Adalet Bakanlığı Avrupa Birliği Genel Müdürlüğü (2010), "Yargılamada Bilirkişilik Müessesesi Hakkında Mukayeseli Çalışma”, Görüşme Taslağı.

Akyol, Şener (1991), Hukuk Usulünde Bilirkişilerle İlgili Bazı Problemler, Mukayeseli Hukukta Bilirkişilik ve Sorunları, İstanbul.

Arslan, Ramazan (2000), "Bilirkişilik, Sorunlar ve Çözüm Önerileri (tebliğ)", İzmir Barosu Yarg1 Reformu 2000 Sempozyumu, 6 Nisan.

Aşçıŏlu, Çetin (2000), “Bilirkişilik Sorunu”, Hukuk Kurultayı, Ankara Barosu Yayını, 2000.

Bulut, Erhan (2001), "Bilirkişi Seçimi ve Bilirkişi Raporlarının Bağlayıcıllı̆̆ı", Mevzuat Dergisi, ss.1-9.

Centel, Nur, Zafer, Hamide (2008), Ceza Muhakemesi Hukuku, (5271 Sayılı Yeni Ceza Muhakemesi Kanunu İle İlgili Mevzuata Göre Yenilenmiş ve Gözden Geçirilmiş 5. Bası), Beta Yayınları, İstanbul, Ocak.

Çınar, Sinan (2009), “Türk Vergi Hukukunda Bilirkişilik Kurumu ve Analizi”, Yayınlanmamış Yüksek Lisans Tezi, Gazi Üniversitesi, Ankara.

Deryal, Yahya (2004), "Bilirkişi Uygulamasında Problemli Alanlar ve Bazı Öneriler", Günışı̆̆ı Dergisi, Şubat.

İnan, Atilla (2005), "Bilirkişiliğin Sosyolojik Gelişimi, Bilirkişi Etiği ve Bilirkişilerin Güncel Sorunları (tebliğ)", İSMMMO Bilirkişi Eğitim Semineri, TÜRMOB Yayını, Ankara, Şubat.

İslamoğlu, Ahmet Hamdi (2009), SPSS Uygulamalı Sosyal Bilimlerde Araştırma Yöntemleri, (1. Bask1), Beta Basım Yayım Dağıtım A.Ş., İstanbul.

İstanbul Barosu (2010), "Türk Hukuk Sisteminde Bilirkişilik”.

<http://www.istanbulbarosu.org.tr/detail.asp?CatID=1\&SubCatID=1\&ID=4866> (14.06.2014)

Kalaycı, Şeref (2010), "Faktör Analizi”, Şeref Kalaycı (Edit.) (2010), SPSS Uygulamalı Çok Değişkenli İstatistik Teknikleri, (5. Baskı), Asil Yayın Dağıtım Ltd. Şti., Ankara.

Kayış, Aliye, "Güvenirlilik Analizi”, Şeref Kalaycı (Edit.) (2010), SPSS Uygulamalı Çok Değişkenli İstatistik Teknikleri, (5. Baskı), Asil Yayın Dağıtım Ltd. Şti., Ankara.

Mecek, Hüseyin (2011), “Ceza Muhakemesinde Bilirkişilik”, Yayınlanmamış Yüksek Lisans Tezi, Selçuk Üniversitesi, Konya.

Özdamar, Kazım (2013), Paket Programlar İle İstatistiksel Veri Analizi, Yenilenmiş 9. Bask1, Nisan Kitabevi, Eskişehir.

Salkaya, Şükrü (2000), 'HUMK'da Bilirkişilik (Ehlivukuf), Uygulama ve Karşılaşılan Sorunlar", TÜRMOB II. Bilirkişi Eğitim Semineri, Ankara. 
Soydan, Başar (2008), “Türk Vergi Yargısında Bilirkişilik”, Yayınlanmamış Yüksek Lisans Tezi, Marmara Üniversitesi, İstanbul.

Sungur, Onur (2010), “Korelasyon Analizi”, Şeref Kalaycı (Edit.) (2010), SPSS Uygulamalı Çok Değişkenli İstatistik Teknikleri, (5. Baskı), Asil Yayın Dağıtım Ltd. Şti., Ankara.

Tankut, Tuğrul, Ersoy, Uğur, "Bilirkişinin Görevi ve Sorumluluğu”.

<http://www.e-kutuphane.imo.org.tr/pdf/12961.pdf > (18.04.2014)

Tanrıver, Süha (2009), "Hukuk Yargısı Bağlamında Bilirkişilikle İlgili Temel Problemler ve Çözüm Arayışları”, Dokuz Eylül Üniversitesi Hukuk Fakültesi Dergisi, Özel Sayı, ss.575-594.

Törüner, Ekrem (2000), "Bilirkişilik Uygulamasında Karşılaşılan Sorunlar”, TÜRMOB II. Bilirkişi Eğitim Semineri, Ankara.

Yıldırım, Ramazan- Odyakmaz, Zehra- Atik, Ayşegül, Çoban- Çalışkan, Ahmet, Ziya- Ersöz, Ahmet, Kürşat- Deniz, Yusuf (2011), “İdare Mahkemeleri Örneğinde Bilirkişilik Uygulamaları”, Selçuk Üniversitesi Hukuk Fakültesi Dergisi, ss.9-38.

Yücel, Ali, Rıza (2011), "Yeni 6100 Sayılı Hukuk Muhakemeleri Yasasında Bilirkişilik”, Türkiye Mühendislik Haberleri Dergisi, ss.67-77. 


\section{EK: Anket Formu}

\begin{tabular}{|c|c|c|c|c|c|c|c|c|c|c|}
\hline \multicolumn{2}{|c|}{$\begin{array}{l}\text { 1.Cinsiyetiniz } \\
\text { ( ) Bayan } \\
\text { ( ) Erkek } \\
\text { 2. Yaşadığınız } \\
\text { il İtanbul } \\
\text { ( ) İtankara } \\
\text { ( ) Ankara } \\
\text { ( ) İzmir }\end{array}$} & $\begin{array}{l}\text { 3.Yaşınız } \\
\text { ( ) } 20-25 \\
\text { ( ) } 25-35 \\
\text { ( ) } 35-45 \\
\text { ( ) } 45 \text { ve üstü }\end{array}$ & $\begin{array}{l}\text { 4. Eğitim } \\
\text { Durumunuz } \\
\text { ( ) Lisans } \\
\text { ( ) Lisansüstü }\end{array}$ & $\begin{array}{l}\text { 5.Mesleki } \\
\text { kıdeminiz } \\
\text { ( ) 5'den az } \\
\text { ( ) } 5-10 \text { aras1 } \\
\text { ( ) } 10-20 \text { arası } \\
\text { ( ) } 20 \text { yıl ve üstü }\end{array}$ & \multicolumn{2}{|c|}{$\begin{array}{l}\text { 6. Unvanınız } \\
\text { ( ) Hakim } \\
\text { ( ) SMMM }\end{array}$} & \multicolumn{4}{|c|}{$\begin{array}{l}\text { 7. Bilirkişiye } 1 \text { yıl içinde giden } \\
\text { /gelen dosya sayısı } \\
\text { () } 10 \text { 'dan az } \\
\text { ( ) } 10-50 \text { aras } 1 \\
\text { ( ) } 51-100 \text { aras } 1 \\
\text { ( ) } 101-500 \text { aras1 } \\
\text { ( ) } 501-1000 \text { arası } \\
\text { ( ) } 1001-1500 \text { aras } 1 \\
\text { ( ) } 1500 \text { ve üstü }\end{array}$} \\
\hline \multicolumn{6}{|c|}{$\begin{array}{l}\text { Aşağıda muhasebe meslek mensubu bilirkişilerin değerlendirilmesi için bazı bilgiler } \\
\text { verilmiştir. Verilen bilgilere göre katılma düzeyinize uygun olan seçeneği işaretleyiniz. }\end{array}$} & 竞竞竞 & 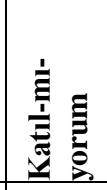 & 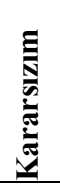 & 范 & 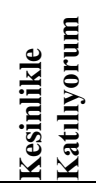 \\
\hline BN1 & \multicolumn{5}{|c|}{ Bilirkişiler, uyuşmazlık konusu ile ilgili ehil ve uzman kişilerdir. } & & & & & \\
\hline BN2 & \multicolumn{5}{|c|}{ Bilirkişilerin, davanın çözümüne yönelik hukuki becerileri vardır. } & & & & & \\
\hline BN3 & \multicolumn{5}{|c|}{ Bilirkişilerin, davanın çözümüne yönelik teknik becerileri vardır. } & & & & & \\
\hline BN4 & \multicolumn{5}{|c|}{ Bilirkişiler, tarafsız ve dürüst bir şekilde görevlerini icra etmektedirler. } & & & & & \\
\hline Gr1 & \multicolumn{5}{|c|}{$\begin{array}{l}\text { Uyuşmazlıkla ilgili dava dosyası yetkili adli makamlarca etraflıca } \\
\text { incelenmektedir. }\end{array}$} & & & & & \\
\hline Gr2 & \multicolumn{5}{|c|}{$\begin{array}{l}\text { Uyuşmazlıkla ilgili hukukî ve genel bilgiler için bilirkişiye } \\
\text { başvurulmamaktadır. }\end{array}$} & & & & & \\
\hline Gr3 & \multicolumn{5}{|c|}{$\begin{array}{l}\text { Uyuşmazlığın çözümü teknik ve özel bilgi gerektiriyorsa bilirkişiye } \\
\text { başvurulmaktadır. }\end{array}$} & & & & & \\
\hline Gr4 & \multicolumn{5}{|c|}{$\begin{array}{l}\text { Aynı uzmanlık alanında, sürekli olarak aynı kişiler bilirkişi olarak } \\
\text { görevlendirilmemektedir. }\end{array}$} & & & & & \\
\hline Gr5 & \multicolumn{5}{|c|}{$\begin{array}{l}\text { Önceden, uyuşmazlık konusu ile ilgili bilirkişi olarak görevlendirilecek kişi } \\
\text { veya kişilerle görüş alış-verişi yapılmaktadır. }\end{array}$} & & & & & \\
\hline Gr6 & \multicolumn{5}{|c|}{$\begin{array}{l}\text { Bilirkişiye sorulacak sorular açık ve ayrıntılı olarak önceden } \\
\text { belirlenmektedir. }\end{array}$} & & & & & \\
\hline Gr7 & \multicolumn{5}{|c|}{ Bilirkișinin görev alanının çevresi, açık ve kesin bir dille çizilmektedir. } & & & & & \\
\hline Gr8 & \multicolumn{5}{|c|}{$\begin{array}{l}\text { Uyuşmazlık konusu ile ilgili gerekli tüm bilgi ve belgeler, bilirkişilere } \\
\text { teslim edilmektedir. }\end{array}$} & & & & & \\
\hline Gr9 & \multicolumn{5}{|c|}{$\begin{array}{l}\text { Bilirkişilerin hukukî statüsü, yetkileri ve yükümlülükleri mevzuatta } \\
\text { belirtilmektedir. }\end{array}$} & & & & & \\
\hline Gr10 & \multicolumn{5}{|c|}{$\begin{array}{l}\text { Gerçeğe aykırı bilirkişilik suçundan dolayı, suçlu sayılan bilirkişilere cezai } \\
\text { yaptırımlar uygulanmaktadır. }\end{array}$} & & & & & \\
\hline Gr11 & \multicolumn{5}{|c|}{ Görevlendirilen bilirkişilere yemin verdirilmektedir. } & & & & & \\
\hline Gr12 & \multicolumn{5}{|c|}{ Bilirkişi ücretleri işin niteliğine göre belirlenmektedir. } & & & & & \\
\hline $\begin{array}{l}\text { Bi } \\
\text { ge } \\
\text { bi }\end{array}$ & \multicolumn{5}{|c|}{$\begin{array}{l}\text { Bilirkişi, sorunun kendi uzmanlık alanına girmediğini ya da özel bilgileri } \\
\text { gerektirdiğini düşündüğünde durumu kendisini görevlendiren makama } \\
\text { bildirmektedir. }\end{array}$} & & & & & \\
\hline BG2 & \multicolumn{5}{|c|}{$\begin{array}{l}\text { Bilirkişiler, kurul teşkil edecek şekilde görevlendirilmeleri durumunda, } \\
\text { kurul şeklinde çalışmaya özen göstermektedirler. }\end{array}$} & & & & & \\
\hline BG3 & \multicolumn{5}{|c|}{$\begin{array}{l}\text { Kurul içinde görevlendirilen farklı bilirkişiler, görüş farklılıklarını, ortak } \\
\text { hazırlanan rapora muhalefet şerhi düşerek belirtmektedirler. }\end{array}$} & & & & & \\
\hline BG4 & \multicolumn{5}{|c|}{$\begin{array}{l}\text { Bilirkişiler, görevlendirme yazısında kendilerine tanınan süre içerisinde } \\
\text { rapor ve eklerini mahkemeye göndermektedirler. }\end{array}$} & & & & & \\
\hline BR1 & \multicolumn{5}{|c|}{ Bilirkişi raporları, başkalarına tanzim ettirilmemektedir. } & & & & & \\
\hline BR2 & \multicolumn{2}{|c|}{ Bilirkişi raporları, ka } & edilebilir, mak & gerçekçi bir gerek & & & & & & \\
\hline
\end{tabular}




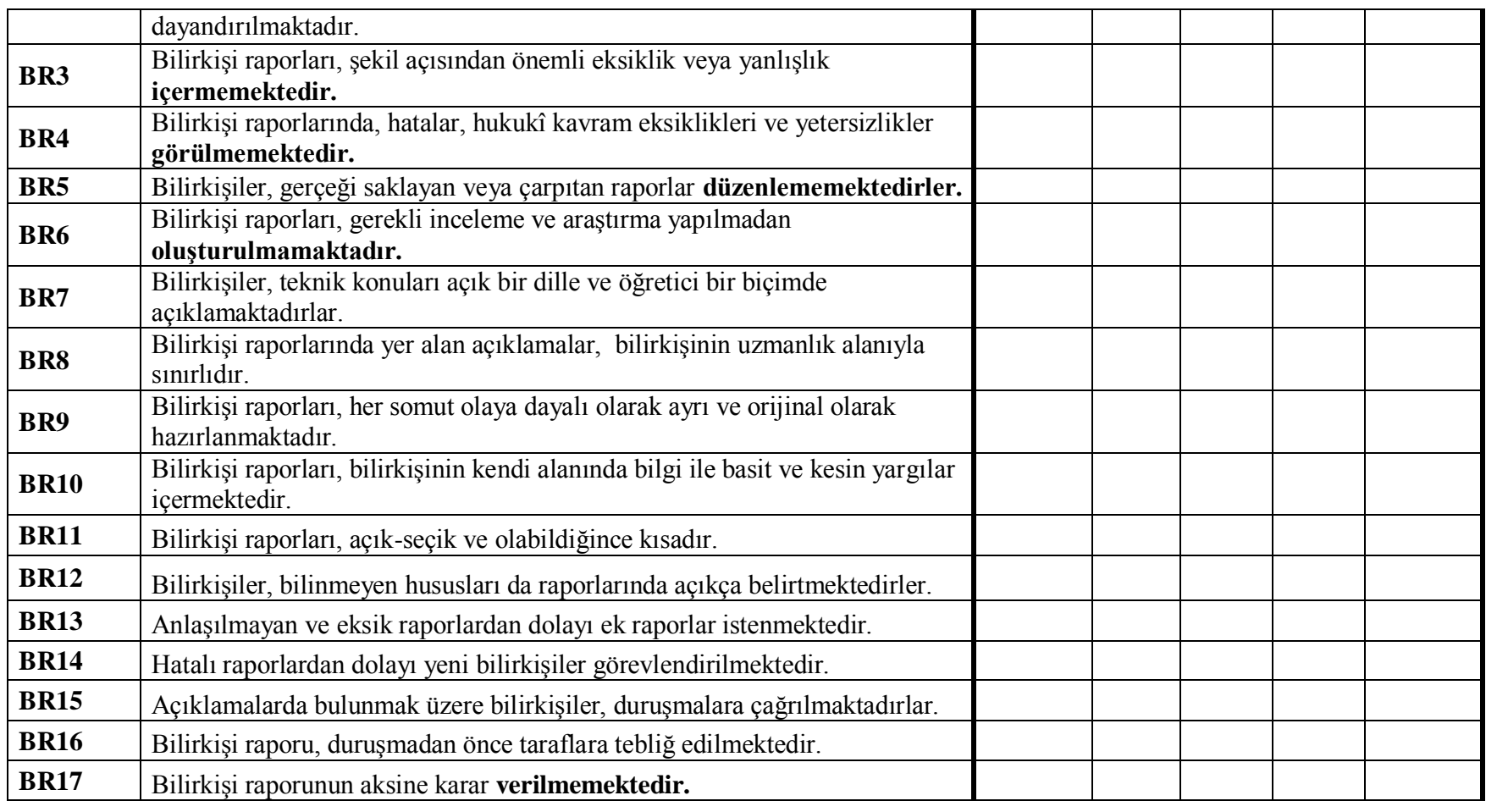


